\title{
Raising the Stakes: Cassava Seed Networks at Multiple Scales in Cambodia and Vietnam
}

\section{OPEN ACCESS}

Edited by:

Ademola Braimoh,

World Bank, United States

Reviewed by:

Yann le Polain de Waroux, McGill University, Canada

Therese Mwatitha Gondwe,

International Institute of Tropical

Agriculture, Zambia

*Correspondence:

Stef de Haan

s.dehaan@cgiar.org;

e.delaquis@cgiar.org

Specialty section:

This article was submitted to Land, Livelihoods and Food Security,

a section of the journal

Frontiers in Sustainable Food Systems

Received: 17 August 2018 Accepted: 17 October 2018 Published: 15 November 2018

Citation:

Delaquis E, Andersen KF, Minato N, Cu TTL, Karssenberg ME, Sok S, Wyckhuys KAG, Newby JC, Burra DD, Srean P, Phirun I, Le ND, Pham NT,

Garrett KA, Almekinders CJM,

Struik PC and de Haan S (2018)

Raising the Stakes: Cassava Seed

Networks at Multiple Scales in

Cambodia and Vietnam

Front. Sustain. Food Syst. 2:73. doi: 10.3389/fsufs.2018.00073

\begin{abstract}
Erik Delaquis ${ }^{1}$, Kelsey F. Andersen ${ }^{2}$, Nami Minato ${ }^{1}$, Thuy Thi Le Cu ${ }^{1}$, Maria Eleanor Karssenberg ${ }^{3}$, Sophearith Sok ${ }^{1}$, Kris A. G. Wyckhuys ${ }^{4,5,6}$, Jonathan C. Newby ${ }^{1}$, Dharani Dhar Burra ${ }^{1}$, Pao Srean $^{7}$, Iv Phirun ${ }^{8}$, Niem Duc Le ${ }^{9}$, Nhan Thi Pham ${ }^{10}$, Karen A. Garrett ${ }^{2}$, Conny J. M. Almekinders ${ }^{3}$, Paul C. Struik ${ }^{11}$ and Stef de Haan $^{1 *}$

${ }^{1}$ International Center for Tropical Agriculture, Hanoi, Vietnam, ${ }^{2}$ Plant Pathology Department, Institute for Sustainable Food Systems, and Emerging Pathogens Institute, University of Florida, Gainesville, FL, United States, ${ }^{3}$ Department of Social Sciences, Wageningen University and Research, Wageningen, Netherlands, ${ }^{4}$ Institute of Applied Ecology, Fujian Agriculture and Forestry University, Fuzhou, China, ${ }^{5}$ School of Biological Sciences, University of Queensland, Brisbane, QLD, Australia, ${ }^{6}$ Institute of Plant Protection, China Academy of Agricultural Sciences, Beijing, China, ${ }^{7}$ Faculty of Agriculture and Food Processing, University of Battambang, Battambang, Cambodia, ${ }^{8}$ Department of Industrial Crops, General Directorate of Agriculture, Phnom Penh, Cambodia, ${ }^{9}$ Faculty of Economics, Tay Nguyen University, Dak Lak, Vietnam, ${ }^{10}$ Hung Loc Agricultural Research Center, Dong Nai, Vietnam, ${ }^{11}$ Centre for Crop Systems Analysis, Department of Plant Sciences, Wageningen University and Research, Wageningen, Netherlands
\end{abstract}

Cassava is one of the most important annual crops in Southeast Asia, and faces increasing seed borne pest and disease pressures. Despite this, cassava seed systems have received scant research attention. In a first analysis of Vietnamese and Cambodian cassava seed systems, we characterized existing cassava seed systems in 2016-2017 through a farmer survey based approach at both national and community scales, with particular focus on identifying seed system actors, planting material management, exchange mechanisms, geographies, and variety use, and performed a network analysis of detected seed movement at the provincial level. Despite their status as self-organized "informal" networks, the cassava seed systems used by farmers in Vietnam and Cambodia are complex, connected over multiple scales, and include links between geographically distant sites. Cassava planting material was exchanged through farmer seed systems, in which re-use of farm-saved supply and community-level exchanges dominated. At the national level, use of self-saved seed occurred in 47 and $64 \%$ of seed use cases in Cambodia and Vietnam, respectively. Movement within communes was prevalent, with 82 and $78 \%$ of seed provided to others being exchanged between family and acquaintances within the commune in Cambodia and Vietnam, respectively. Yet, meaningful proportions of seed flows, mediated mostly by traders, also formed inter-provincial and international exchange networks, with 20\% of Cambodia's seed acquisitions imported from abroad, especially neighboring Vietnam and Thailand. Dedicated seed traders and local cassava collection points played important roles in the planting material distribution network at particular sites. Sales of planting material were important means of both acquiring and providing seed in both countries, and commercial sale was more prevalent in high-intensity than in low-intensity production sites. Considerable variability existed in local seed networks, depending on the intensity of production and integration with trader networks. Adapted innovations are needed to 
upgrade cassava seed systems in the face of emerging pests and diseases, taking into account and building on the strengths of the existing systems; including their social nature and ability to quickly and efficiently distribute planting materials at the regional level.

Keywords: seed systems, Manihot esculenta, seed flow, vegetatively propagated crops, network analysis

\section{INTRODUCTION}

Cassava (Manihot esculenta Crantz) is a perennial root crop originating from the tropical Americas (Nassar and Ortiz, 2009), and grown on $>3.5 \mathrm{M}$ ha in Southeast Asia, primarily as a smallholder cash crop serving global starch-based industrial markets (Cramb et al., 2017). From 2000 to 2016, Cambodia and Vietnam have both experienced rapid increases in cassava area, with planted area in Cambodia increasing 40-fold, from 16,000 to 684,070 ha (MAFF, 2017), and Vietnam registering a 2.4fold increase, from 237,600 to 569,900 ha (GSO, 2017). In both countries the bulk of cassava roots are produced by smallholder farmers, although larger commercial plantations have begun increasing in number (Ziegler et al., 2009). Vietnamese factories predominantly process starch from fresh roots, or produce dried chips for export, while the Cambodian sector primarily exports raw materials (either fresh roots or dried chips) to neighboring Vietnam and Thailand for processing and re-export (SNV, 2015). The Southeast Asian market as a whole is driven largely by derived demand from Chinese industrial processors (Cramb et al., 2017).

Vietnam and Cambodia's cassava boom has coincided with the emergence and spread of a host of pests and diseases, including the cassava mealybug and cassava witches broom disease (CWB) (Alvarez et al., 2013; Graziosi et al., 2016). CWB, caused by a systemic phytoplasma infection, is likely spread by an as yet unknown insect vector, but its ready transmission through infected planting material has facilitated its spread at the regional level (Graziosi et al., 2016). The most recent arrival is a member of the cassava mosaic virus family of geminiviruses, the Sri Lanka Cassava Mosaic Virus (SLCMV) (Wang et al., 2016). From the 1980s to present, Africa has suffered a particularly damaging epidemic of cassava mosaic disease, which spread rapidly across the continent's several million square kilometers of cassava area to become one of the most economically important plant diseases in Africa (Legg et al., 2011). Endemic to India and Sri Lanka, SLCMV is disseminated both by Bemisia tabaci whitefly, and through the movement of infected planting materials (Legg et al., 2011). Transmission by infected planting materials has been a major source of infection in the East African cassava mosaic virus epidemic (Legg, 1999), as well as in India (Legg et al., 2015). Southeast Asian cassava varieties do not currently carry resistance for cassava mosaic viruses, and are hence at high risk for infection and further transmission of the disease. The appearance of SLCMV is part of a larger pattern of pest and disease invasion in Southeast Asian cassava (Graziosi et al., 2016), including interacting co-infections by several pest species (Wyckhuys et al., 2017). Other diseases transmitted through planting materials but not yet reported in Asia, such as cassava brown streak disease, pose further future risks (Legg et al., 2015). These threats to the multi-billion dollar regional industry, all transmissible by the movement of contaminated planting materials, call for an increased understanding of existing cassava seed systems.

Cassava can be multiplied vegetatively from stem, meristem, leaf-bud, and root-tip cuttings, or sexually from botanical seed (Danso and Ford-Lloyd, 2003; Rajendran et al., 2005; Duputié et al., 2007; Hegde et al., 2016). Southeast Asian producers use the woody $\sim 2 \mathrm{~m}$ stems of mature plants for cassava propagation, chopping them into $15-25 \mathrm{~cm}$ cuttings immediately before planting (FAO, 2001; Howeler, 2014). With true seed playing a negligible role, stems or "stakes" are equivalent to "seeds" in cassava production systems (Coomes, 2010), and we use the terms interchangeably here. As in other vegetatively propagated crops, the cassava seed system is characterized by bulky planting material (Ceballos et al., 2011; Legg et al., 2014), low multiplication rates (Elias et al., 2007; Legg et al., 2014), low seed dormancy (Dyer et al., 2011), maintenance of the genetic identity of varieties as clones from one generation to the next (Ceballos et al., 2015), domination of self-regulated or "informal" seed exchange (Coomes et al., 2015), and high potential buildup of seed-borne pests and diseases (Howeler, 2014; Thomas-Sharma et al., 2017). Planting one hectare of cassava requires $\sim 1,000 \mathrm{~kg}$ of stakes, compared to $\sim 25 \mathrm{~kg} / \mathrm{ha}$ of maize seed (Henry, 1991), and a single cassava plant may only produce 5-10 high-quality cuttings, compared to 300 seeds for maize (FAO, 2001; Ceballos et al., 2011). Annual replanting of the $>1.2 \mathrm{M}$ ha of cassava in Vietnam and Cambodia therefore requires a network of supply for $\sim 1.2-1.8 \mathrm{Bn}$ viable stakes, at the right time, and in the right places for planting.

Seed network analysis, also called seed flow mapping (Tadesse et al., 2016), involves analyzing seed provision and acquisition (links) between pairs of actors (nodes) (Almekinders et al., 1994; Bentley et al., 2017; Buddenhagen et al., 2017). Diverse actors may be involved from the public and private sectors, while seed flows may be characterized at spatial scales including households, villages, regions, and nations (Zimmerer, 2003; MoslonkaLefebvre et al., 2011). Seed networks can be characterized by the social categories of nodes (e.g., gender, trust, ethnicity, religion), and whether social categories influence the probability of links (dynamic or static) based on economics (e.g., involving prices and volumes), technical characteristics (e.g., based on seed categories and rates of renewal), geography (e.g., based on proximity), or disease status (e.g., infected or uninfected with a particular pathogen). Seed exchange mechanisms include sale, barter, gifts, and loans, with trade as simple as gifts between neighbors, or as complex as cross-border transactions involving intermediate actors and redistribution networks. Analysis of seed networks as potential epidemic pathways can help to identify key locations for sampling and mitigation of pathogens in seed networks, and to evaluate the roles of different actors in those 
epidemics (Buddenhagen et al., 2017; Andersen et al., 2018; Garrett et al., 2018).

Seed systems are often described as being formal (e.g., registered or certified seed), informal (e.g., farmer or local seed), and mixed or integrated [e.g., quality declared seed (QDS)]. The weaknesses of such a rigid framework are well-recognized (Coomes et al., 2015), and may promote misconceptions about system strengths and weaknesses (Thiele, 1999; Coomes et al., 2015; Urrea-Hernandez et al., 2016), particularly given the growing recognition and appreciation of mixed or integrated models facilitating smallholder access (ASF, 2016; Luby and Goldman, 2016; McGuire and Sperling, 2016; Montenegro de Wit, 2017). Here we use the terms formal and informal for simplicity, but with full recognition of their limitations.

Globally, cassava seed systems are typically informal, and managed without major public sector involvement in the production, supply, or quality control of planting materials (Elias et al., 2000; Sardos et al., 2008; Dyer et al., 2011; Legg et al., 2014; McGuire and Sperling, 2016). Until recently, serious seed-borne pests, viruses, and bacterial or phytoplasma diseases were mostly absent in the region, allowing the status quo to continue with little serious scrutiny (Legg et al., 2014; Graziosi et al., 2016). What is "known" about cassava seed networks in Southeast Asia (as commonly occurs elsewhere) is often based on generalizations, isolated case studies, or anecdotal opinion, rather than systematic analysis (Dyer et al., 2011). Seed system interventions are increasingly proposed as a development focus to cope with cassava's emerging phytosanitary challenges (Legg et al., 2014; McQuaid et al., 2016), yet it remains common for research and development of "clean seed systems" to predominantly focus on single segments of the supply chain, without necessarily integrating innovations (e.g., FAO, 2010; Shiji et al., 2014; Castañeda-Méndez et al., 2017). Elucidating the structure and functioning of existing seed systems is an essential prerequisite to designing effective and impactful seed system innovations acceptable to local stakeholders.

The present study characterizes cassava seed systems in Cambodia and Vietnam at individual, community, and provincial/national scales, including the mechanisms and actors involved in seed procurement, exchange, and movement. We present a baseline assessment and provide, to our knowledge, the first systematic investigation of national cassava seed systems in Southeast Asia. Our specific objectives were to (i) understand farmer seed use profiles and behavior, (ii) determine the actors and mechanisms involved in seed procurement and their relative importance (including gendered contributions), (iii) characterize seed networks including the spatial reach of seed, transaction volumes, and regions of high importance, and (iv) analyze the existing policy environment.

\section{MATERIALS AND METHODS}

\section{Surveys, Study Site Selection, and Sampling}

Two types of stakeholder surveys were conducted: (i) a binational survey, and (ii) a detailed subnational survey at four district level sites (Figure 1). The topics, sample sizes, and implementation dates for each survey are presented in Table $\mathbf{1 .}$ These surveys gathered information based on the current cropping season, which typically ranges from 8 to 11 months in the study region. Respondents in the subnational survey were also asked about seed purchase history and amounts spent on seed over the previous three seasons. Trader surveys were conducted following the conclusion of the subnational survey.

The bi-national survey was conducted in tandem with a parallel study evaluating SLCMV incidence. Sampling methods were based on previous studies monitoring cassava mosaic virus outbreaks in Africa (Sseruwagi et al., 2004; Legg et al., 2011). For the bi-national survey, 15 districts per country representing areas of significant cassava production were selected (Figure 1). An additional 16th district, Koun Mom in Ratanakiri province, Cambodia, was added (the site of first detection of the recent SLCMV outbreak in Southeast Asia, Wang et al., 2016). In both countries, district selection was adjusted with the input of local expert authorities based on current presence of mature cassava plantations in the field, updated information on changes in cassava area from district officers, and logistic issues of sampling accessibility. Selected sites therefore included important cassava producing districts from important production provinces, representative of the national situation in each country. Within each selected district, 15 approximately equidistant fields were selected along the primary motorable road. For each selected site, respondents were asked to identify the household member most responsible for cassava production activities; this individual was then interviewed. Surveys were conducted by trained enumerators supported by local authorities (in Cambodia the General Directorate of Agriculture, supported by Provincial Department of Agriculture, Forestry, and Fisheries; in Vietnam the Plant Protection Department and the Plant Protection Research Institute) in Khmer and Vietnamese.

For the subnational survey, one high-intensity cassava production site and one low-intensity site were selected in each country to compare trends in seed exchange behavior, geography, and actors involved. High-intensity production sites were defined as well-established, high density cassava producing districts, while low-intensity production sites had lower cassava density. These contrasting contexts were selected due to their potential effects on multiple aspects of seed supply, demand, accessibility, and presence of newly established fields, which by their lack of a previous cropping cycle necessitate seed imports. The selection of these districts was based on planted area timeline series where available (GSO, 2017; NIS, 2017), supplemented with information from local experts and authorities with knowledge of current cassava production at the district scale. Target communes within selected districts were chosen based on the above criteria and expert advice from national implementing partners (Tay Nguyen University for Dak Lak, Hung Loc Agricultural Research Center for Tay Ninh, University of Battambang for Battambang, and Royal University of Agriculture for Ratanakiri).

In Vietnam, the border of Tan Hiep and Tan Hoi communes, Tan Chau district (pop. 106,264, GSO, 2017) of Tay Ninh province was selected as a high-intensity site. Ea Sar commune of Ea Kar district (pop. 142,525), Dak Lak province was selected as a contrasting low-intensity site. In Cambodia, the high-intensity site was spread across four communes on the border of Banan 


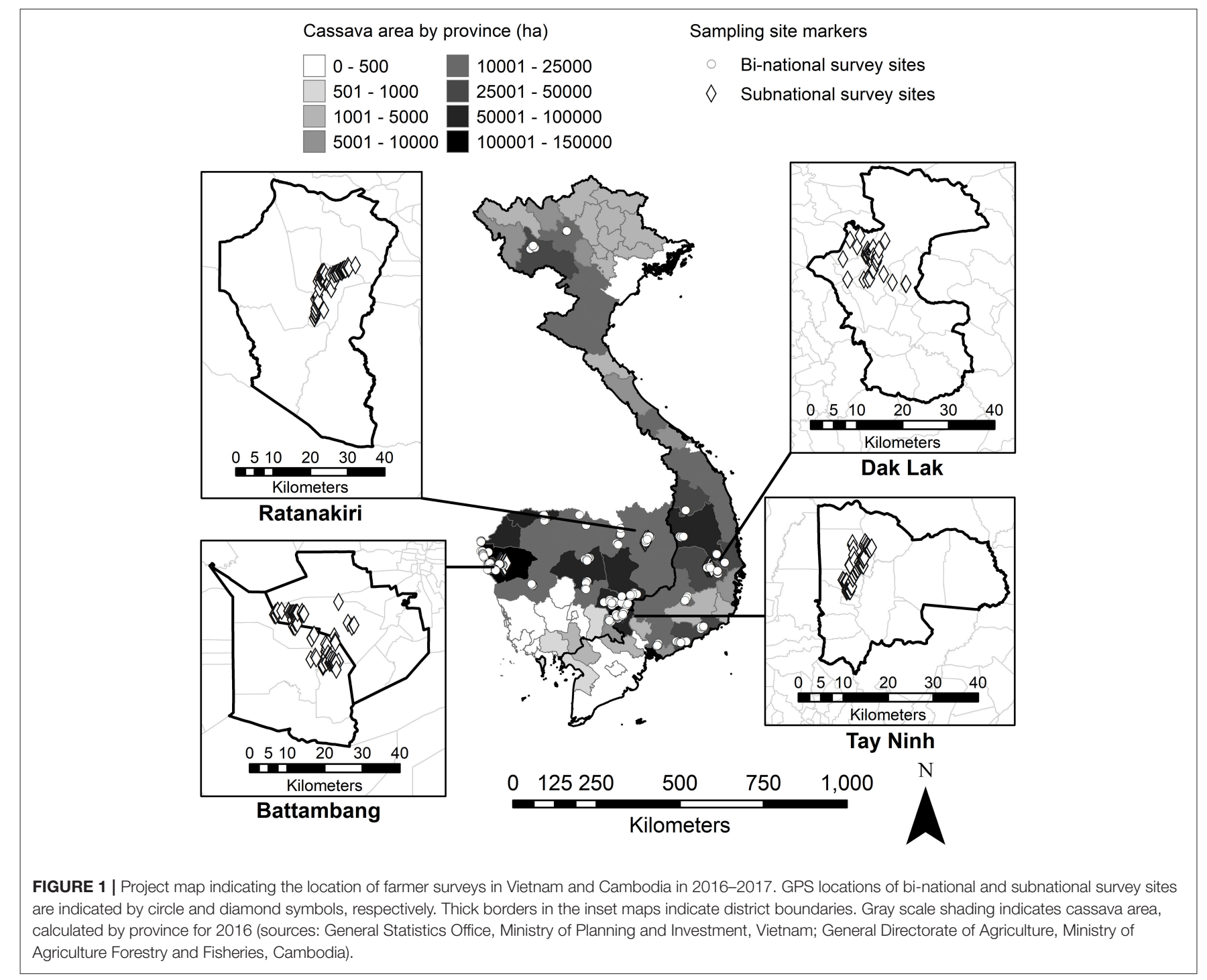

(pop. 92,138) and Rotanak Mondul (pop. 41,170) districts in Battambang province, while Trapeang Chres commune, Koun Mom district (pop. 15,505), Ratanakiri province, was selected as the low-intensity site. Respondents within communes were randomly selected within a $5 \mathrm{~km}$ sampling radius, aiming for high completeness.

To gather information on trader activities and characteristics, enumerators attempted to contact all traders identified by respondents of the subnational survey for follow-up trader interviews by phone or in person. Only those successfully contacted and agreeing to participate in the interview were surveyed.

For the purposes of this study, traders were defined as those specializing in mediating exchange of planting materials beyond their own needs and supply. Respondents provided seed transaction information relating to exchange of seed for the 2015-2016 cropping season (leading to the plants which were growing in their field at the time of survey). Transactions here refer to all sources of seed contributing to the farmer's seed supply (acquisition), and seed provided to others (provision). In describing the geographic origin or destination of seed, respondents were requested to provide the origin of the seed in that season (i.e., the source location, not necessarily the actor's location at time of purchase or sale). Hence the study attempted to determine movement of material over the course of a season, rather than the location of intermediaries.

\section{Data Analysis}

All data was recorded on paper questionnaires, translated from Khmer or Vietnamese to English, digitized, and analyzed using R. Maps were created in ArcMap 10.3 and R. Seed transactions of different types among categories of actors at the subnational survey sites were visualized using parallel sets, and Fruchterman-Reingold plots were used to visualize seed exchange among individual respondents (Supplementary Material 1). To characterize regional seed flows, bi-national survey data was aggregated to province level. Nodes in the estimated network represent surveyed provinces as well as non-surveyed provinces 
TABLE 1 | Characteristics of project surveys implemented in Vietnam and Cambodia, 2016-2017.

\begin{tabular}{|c|c|c|c|c|}
\hline Survey & Type & Topics covered & Sample size and locations & Survey date \\
\hline National survey & Household survey & $\begin{array}{l}\text { (a) Respondent information } \\
\text { (b) Seed use overview } \\
\text { (c) Field and household data }\end{array}$ & $\begin{array}{l}\text { Cambodia: } 16 \text { districts, } n=240 \\
\text { Vietnam: } 15 \text { districts, } n=206\end{array}$ & Nov.-Dec., 2016 \\
\hline Subnational survey & Household survey & $\begin{array}{l}\text { (a) Respondent information } \\
\text { (b) Seed use overview } \\
\text { (c) Field and household data } \\
\text { (d) Seed quality } \\
\text { (e) Affordability/profitability } \\
\text { (f) Information sources }\end{array}$ & $\begin{array}{l}\text { Battambang, Cambodia: } n=100 \\
\text { Ratanakiri, Cambodia: } n=100 \\
\text { Tay Ninh, Vietnam: } n=100 \\
\text { Dak Lak, Vietnam: } n=94\end{array}$ & Feb.-Mar., 2017 \\
\hline Trader survey & Individual follow-up survey & $\begin{array}{l}\text { (a) Respondent information } \\
\text { (b) Livelihood and seed business } \\
\text { (c) Seed exchange } \\
\text { (d) Seed quality and handling } \\
\text { (e) Affordability/profitability } \\
\text { (f) Cassava health information sources }\end{array}$ & $\begin{array}{l}\text { Ratanakiri, Cambodia: } n=1 \\
\text { Tay Ninh, Vietnam: } n=12 \\
\text { Dak Lak, Vietnam: } n=7\end{array}$ & Feb.-Mar., 2017 \\
\hline
\end{tabular}

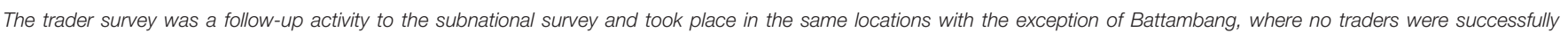
interviewed.

that were designated as seed "sources" or "sinks" by survey respondents. In cases where finer-scale seed source providences were not reported, transactions were aggregated to country level. Links represent aggregated stake transactions between nodes (provinces or countries). To account for differences in sample sizes between surveyed provinces, link weights were calibrated by dividing the total number of stakes by the number of farmers surveyed in the "source" province. Link weights were thus the estimated number of stakes exchanged per household. Note that the nature of the survey allows seed movement to be estimated only in certain directions. For example, the role of Thailand and Laos in the network were only evaluated in terms of reported seed movement from these countries into Vietnam and Cambodia, while reported seed movement to, from, and within Vietnam and Cambodia was analyzed in depth.

Transactions were aggregated in an adjacency matrix to construct a network graph with provinces as nodes, and seed exchange as links. To understand the role of provinces as net "importers" or "exporters", node in- and out-strength were calculated as the sum of the volumes of incoming and outgoing stakes from each province (not including self-loops). Network statistics, such as node degree, were also calculated to understand the role of provinces in the seed exchange network. Network analysis was conducted and visualized in R, using dplyr (Wickham and Francois, 2016), igraph (Csardi and Nepusz, 2006), and custom R code.

\section{RESULTS}

\section{Socioeconomic and Basic Production Characteristics \\ Bi-National Survey}

In Cambodia $21 \%$ of respondents (those identified as mainly responsible for cassava cultivation activities) were female, while in Vietnam 24\% of respondents were female. Overall, farmers in Vietnam had more experience growing cassava $(12.8 \pm 9.5$ years) than their Cambodian counterparts $(6.3 \pm 5.0$ years, \pm here and hereafter represents standard deviation). The cassava value chain in both countries was industry-oriented; none of the survey respondents reported producing cassava to be eaten domestically. For farmers in both countries cassava was a major cash crop, generating on average about half of their reported household-level income.

Average farm sizes in Cambodia were three times larger than those in Vietnam (6.4 \pm 9.0 ha, vs. $2.0 \pm 2.5$ ha, respectively). Similar differences were observed for farm area dedicated to cassava; $3.9 \pm 5.6$ ha in Cambodia vs. $1.4 \pm 1.3$ ha in Vietnam. The use of fertilizers was much lower in Cambodia (14.2\%) than in Vietnam (73.1\%). Pests and diseases were often mentioned as being current problems in Cambodia (75\%), and less so in Vietnam (45\%). Pesticide use was high in Cambodia (78\%) and Vietnam (89\%), but products used were commonly not known to the farmer, and included a diverse array of mentions of herbicides, insecticides, and other compounds.

Cassava varietal diversity managed by individual households was low, with most households describing maintaining a single variety per farm in both countries (Table 2). In Vietnam the average number of varieties reported per household was $1.1 \pm$ 0.3 , with a maximum portfolio of three varieties, while Cambodia averaged $1.4 \pm 0.6$, with a maximum portfolio of four varieties. However, it was clear across the survey sites that farmers had difficulty distinguishing varieties and often could not provide a name at all. Additional farm characteristics are presented in Supplementary Material 2.

\section{Subnational Surveys}

In the Cambodian sites, $26 \%$ of respondents were female in Battambang and $47 \%$ were female in Ratanakiri. In Vietnam, $10 \%$ of Tay Ninh respondents were female, while $49 \%$ were female in Dak Lak. The number of years of cassava cropping experience equally varied: $2.7 \pm 1.4,3.2 \pm 1.9,10.3 \pm 6.5$, and $7.6 \pm 3.8$ years per household in Battambang, Ratanakiri, Tay Ninh, and Dak Lak, respectively. The four sites were similar 
TABLE 2 | Number of varieties maintained at the farm level by producers in the 2016-2017 cassava season in both bi-national and subnational surveys (\% respondents), with $\mathrm{KH}$ indicating Cambodia and $\mathrm{VN}$ indicating Vietnam.

\begin{tabular}{|c|c|c|c|c|c|c|}
\hline \multirow[t]{3}{*}{ Number of varieties } & \multicolumn{2}{|c|}{ National surveys } & \multicolumn{4}{|c|}{ Subnational survey } \\
\hline & \multirow[b]{2}{*}{$\mathbf{K H}$} & \multirow[b]{2}{*}{ VN } & \multicolumn{2}{|c|}{ High intensity } & \multicolumn{2}{|c|}{ Low intensity } \\
\hline & & & Battambang (KH) & Tay Ninh (VN) & Ratanakiri (KH) & Dak Lak (VN) \\
\hline 1 & 69 & 93 & 74 & 99 & 54 & 97 \\
\hline 2 & 25 & 6 & 24 & 1 & 41 & 2 \\
\hline 3 & 6 & 1 & 1 & 0 & 3 & 1 \\
\hline 4 & 0 & 0 & 1 & 0 & 2 & 0 \\
\hline Sample (n) & 240 & 206 & 100 & 100 & 100 & 94 \\
\hline \multirow[t]{2}{*}{ Average \# varieties (SD) } & 1.38 & 1.09 & 1.29 & 1.01 & 1.53 & 1.04 \\
\hline & $(0.62)$ & $(0.30)$ & $(0.54)$ & $(0.1)$ & $(0.66)$ & $(0.25)$ \\
\hline Range & $1-4$ & $1-3$ & $1-4$ & $1-2$ & $1-4$ & $1-3$ \\
\hline
\end{tabular}

in terms of household size (4.7-5.5 members), and number of household members involved in full-time farming (2.16-2.93). In Cambodia, harvested roots were primarily sold to traders $(41 \%)$ or collection points (55\%), while in Vietnam, $8 \%$ of respondents sold roots to collection points, $53 \%$ sold to traders, and $42 \%$ sold directly to factories. Participation in more than one root value chain was rare.

The total size of cropped land per household in Dak Lak (2.6 ha \pm 2.5$)$ was about half of that in the other three sites $(5.6 \pm$ 6.3; 5.5, \pm 4.4 ; and $5.5 \pm 11.3$ ha in Battambang, Ratanakiri, and Tay Ninh, respectively). The average areas dedicated to cassava per household were variable: $3.4 \pm 4.0,2.4 \pm 1.8,4.3 \pm 9.8$, and $1.6 \pm 2.0$ ha per household in Battambang, Ratanakiri, Tay Ninh, and Dak Lak, respectively. The variability in these values reflects the inclusion of some particularly large farms, in both countries found primarily in the high-intensity production sites, with maximum cassava areas of 40 ha in Battambang and 75 ha in Tay Ninh. Between 94 and 100\% of respondents indicated that a neighboring field was growing cassava, demonstrating the near-contiguous nature of the cassava landscape in Vietnam and Cambodia's key production zones.

High levels of pesticide use were reported ( $>80 \%$ in both Cambodian sites; $\sim 60 \%$ in both Vietnamese sites), although the names and ingredients of the products used were typically unknown, with colloquial or generic descriptive terms often employed, including the color of the product bottle, or the specific insects or symptoms farmers wished to eliminate. The use of insecticide was noted in $17,51,56$, and $34 \%$ of cases in Battambang, Ratanakiri, Tay Ninh, and Dak Lak, respectively. In Ratanakiri alone, termiticide was singled out by respondents as a separate category, and its use mentioned by $41 \%$ of respondents.

Across the four study sites, between 81 and $95 \%$ of respondents intended to continue growing cassava, despite global markets driving low cassava prices during the study year. All four sites were characterized by low varietal diversity (Table 2), but different frequency of seed purchase over the three previous cropping seasons (Table 3). In each year fewer farmers in Dak Lak and Ratanakiri (7-10 and 14-19\%, respectively), purchased planting materials, compared to Battambang or Tay Ninh (22-30 and 33-63\%, respectively), and the average amount spent on stakes was also lower at the two former sites. Total average price paid was reported, rather than calculated amounts proportional to farm area, due to many factors, including changing land sizes over the 3 year period, variable partial and whole replacements of seed supply, and fluctuating seed prices.

\section{Seed Network Actors Bi-National Survey}

At the national level, farmers' own saved seed was the most frequently used source (Table 4). In Cambodia 39\% of respondents used exclusively their own saved seed, 35\% used exclusively an off-farm source, and $26 \%$ used seeds from a combination of sources. In Vietnam $63 \%$ of farmers used exclusively their own farm saved seed, $30 \%$ used exclusively an off-farm source, and only $7 \%$ used a combination of sources.

After farm-saved seed, other farmers within the community known by the respondent were the most common source of seed in both countries, making up a further 26 and $20 \%$ of seed used in Cambodia and Vietnam, respectively. Both countries had fewer transactions with farmers outside their communities ( $4 \%$ in each case) and other farmers they did not know (3\% in Cambodia and $1 \%$ in Vietnam). In Cambodia traders played a significant role as providers of seed (18\%), while less so in Vietnam (3\%). In Vietnam $6 \%$ of seed originated from agroinput dealers and $1 \%$ from local government, while in Cambodia starch factories (1\%) and local markets (1\%) were mentioned.

Farmers in both countries overwhelmingly provided stakes to other farmers within their own communities. In Cambodia $82 \%$ of seed provisions to others were directed to other farmers the respondent knew within the community, and the remaining $18 \%$ were to farmers that the respondent did not know (Table 4); often farmers passing by the household during the postharvest period of stake surplus and asking for stakes. In Vietnam, provision of seed to farmer acquaintances within the community were responsible for $78 \%$ of provision interactions, while $13 \%$ were to farmers the respondent did not know. However, in Vietnam traders accounted for an important $9 \%$ of provision transactions, compared to none in Cambodia. 
TABLE 3 | Frequency of cassava seed purchase and average total expenditure on seed per household (expressed in USD adjusted to 2017 exchange rates) when cassava seed was purchased in three consecutive seasons at high and low production intensity sites in Cambodia (KH) and Vietnam (VN).

\begin{tabular}{|c|c|c|c|c|c|c|c|c|}
\hline & \multicolumn{4}{|c|}{ High intensity } & \multicolumn{4}{|c|}{ Low intensity } \\
\hline & $\%$ Buying & Avg. USD & $\%$ Buying & Avg. USD & $\%$ Buying & Avg. USD & $\%$ Buying & Avg. USD \\
\hline 2014 & 22 & 342 & 33 & 132 & 16 & 83 & 10 & 84 \\
\hline 2015 & 29 & 285 & 52 & 199 & 19 & 248 & 10 & 70 \\
\hline
\end{tabular}

TABLE 4 | Seed source and acquisition types reported in Cambodia (KH) and Vietnam (VN) in 2016, presented as percentages of total recorded seed exchanges.

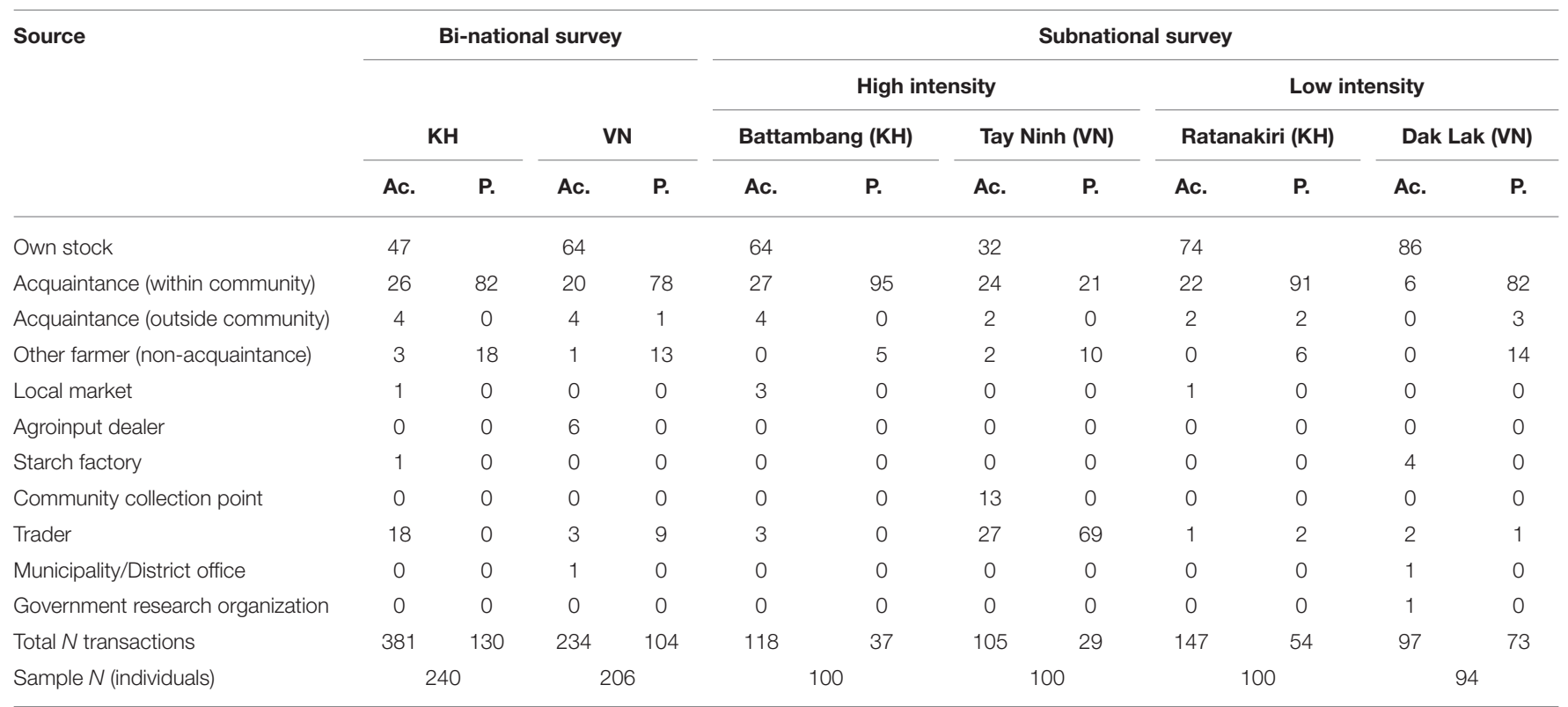

"Ac." denotes seed acquisition, while "P." denotes seed provision.

\section{Subnational Surveys}

Farmer-farmer exchanges dominated, while traders were involved in $<3 \%$ of seed transactions in all sites, with the exception of Tay Ninh, where $36 \%$ of exchanges involved traders, and $13 \%$ of farmer seed acquisition transactions involved a community collection point (Table 4). Seed exchanges involving government and private industry actors (e.g., starch factories) only occurred at low frequency in Dak Lak, while in Battambang three individuals mentioned buying stakes at a local market.

Cambodian household decisions on the acquisition of stakes were made jointly by both males and females in 70 and $67 \%$ of cases in Battambang and Ratanakiri, respectively (see Supplementary Material 1). In Vietnam, in Tay Ninh, $73 \%$ of respondents indicated that male household heads alone were responsible for making these decisions. In Dak Lak, decisions were made equally frequently by the male household head alone, female household head alone, and both together.

In both of the low-density sites, most farmers relied on selfsaved seed, but also interacted frequently, exchanging seed with multiple others in the community, while traders were more rare
(Figure 2). Battambang farmers saved their own seed less than in the low-intensity sites, exchanged mostly with each other, and when they did exchange relied on few trade partners. Conversely in Tay Ninh some farmers interacted with multiple traders.

In both of the high-intensity sites responsibility for cassava cropping was dominated by men, while the low production intensity sites reported gender involvement approaching parity (Figure 2). At all sites, women's contribution to the total number of seed acquisitions from others approximated their gender proportion in the total sample.

\section{Seed Supply and Provisioning Mechanisms and Volumes \\ Bi-National Survey}

A total of 840 unique seedr provision and acquisitions were recorded in the bi-national survey, with farm-saved materials accounting for 47 and $64 \%$ of seed used in Cambodia and Vietnam, respectively (Table 4). In addition, 71 and $84 \%$ of respondents indicated that they intended to re-use the current year's seeds in the following season in 

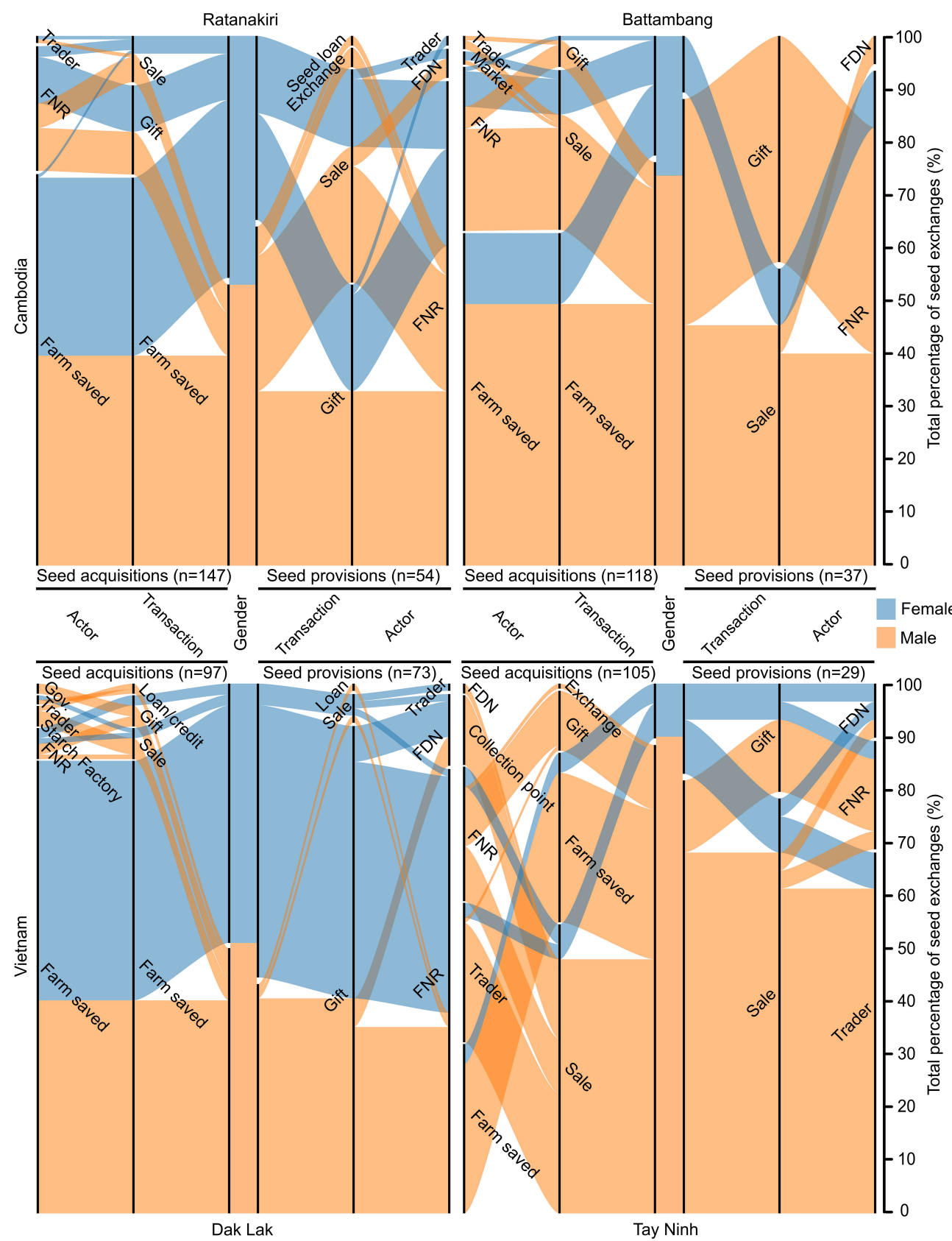

FIGURE 2 | Seed exchange acquisitions, provisions, actors, and mechanisms recorded in the 2016 growing season, at each of four sites in Cambodia and Vietnam, showing relationships between categories of actors and types of transactions. Low production intensity sites are located on the left, with high production intensity sites on the right. Total sample size is 100 for each site except Dak Lak $(n=94)$. Black vertical bars represent $100 \%$ stacked percentages. "Actor" indicates identified sources and sinks of cassava planting material, with "FNR" indicating "farmer/neighbor/relative," while "FDN" indicates "farmer I do not know personally." "Transaction" indicates socioeconomic mechanism of exchange for each acquisition and provision. Gender segments for each of acquisitions and provisions indicate the relative gendered contribution to the total number of transactions. The center columns of each subplot represent the gender proportion of survey respondents at each location.

Cambodia and Vietnam, respectively. However, in Cambodia high proportions of seed purchase were observed (43\%), followed by gifts (10\%). Conversely, in Vietnam a lower percentage of stake purchases was reported (15\%) and gifts were more common (13\%), while a further $7 \%$ of acquisitions were listed as exchange/barter transactions (Table 5).

Over all stake acquisitions recorded, omitting self-provided seed, the average numbers of stakes per acquisition were 8,583 $\pm 17,761$ in Cambodia and $1,927 \pm 2,513$ in Vietnam. Over 
TABLE 5 | Methods of seed exchange reported at one high and one low cassava production intensity site each in Cambodia (KH) and Vietnam (VN) in 2016, presented as percentages of total exchanges at each site.

\begin{tabular}{|c|c|c|c|c|c|c|c|c|c|c|c|c|}
\hline \multirow[t]{4}{*}{ Method of exchange } & \multicolumn{4}{|c|}{ Bi-national survey } & \multicolumn{8}{|c|}{ Subnational survey } \\
\hline & & & & & & High & sity & & & Low & sity & \\
\hline & \multicolumn{2}{|c|}{$\mathbf{K H}$} & \multicolumn{2}{|c|}{ VN } & \multicolumn{2}{|c|}{ Battambang (KH) } & \multicolumn{2}{|c|}{ Tay Ninh (VN) } & \multicolumn{2}{|c|}{ Ratanakiri (KH) } & \multicolumn{2}{|c|}{ Dak Lak (VN) } \\
\hline & Ac. & P. & Ac. & P. & Ac. & P. & Ac. & P. & Ac. & P. & Ac. & P. \\
\hline Save own stocks & 47 & & 65 & & 64 & & 32 & & 74 & & 86 & \\
\hline Exchange/barter & 0 & 2 & 7 & 45 & 0 & 0 & 1 & 0 & 0 & 4 & 0 & 0 \\
\hline Gift & 10 & 62 & 13 & 34 & 6 & 43 & 11 & 21 & 17 & 54 & 6 & 93 \\
\hline Purchase & 43 & 36 & 15 & 21 & 31 & 57 & 55 & 79 & 9 & 41 & 6 & 5 \\
\hline Voucher/coupon & 0 & 1 & 0 & 0 & 0 & 0 & 0 & 0 & 0 & 0 & 0 & 0 \\
\hline Seed Loan & 0 & 0 & 0 & 0 & 0 & 0 & 0 & 0 & 0 & 2 & 1 & 0 \\
\hline Money credit & 0 & 0 & 0 & 0 & 0 & 0 & 0 & 0 & 0 & 0 & 1 & 1 \\
\hline Total $\mathrm{N}$ transactions & 381 & 130 & 234 & 104 & 118 & 37 & 105 & 29 & 147 & 54 & 97 & 73 \\
\hline
\end{tabular}

"Ac." denotes seed acquisition, while "P." denotes seed provision.

all recorded stake provisions to others, the average numbers of stakes exchanged per provision were 7,261 $\pm 18,764$ in Cambodia and 5,443 $\pm 12,162$ in Vietnam.

\section{Subnational Survey}

A total of 660 seed provision, and acquisitions were recorded in the subnational survey, averaging 1.56 seed transactions per respondent in Battambang, 2.01 in Ratanakiri, 1.34 in Tay Ninh, and 1.81 in Dak Lak. The most common strategy was re-use of own farm-saved seed in Battambang, Ratanakiri, and Dak Lak $(59,69$, and $87 \%$ of respondents, respectively). Conversely, in Tay Ninh only $30 \%$ of farmers relied on self-saved seed alone. The use of sources other than farm-saved seed occurred with $66 \%$ of farmers in Tay Ninh, 13\% in Dak Lak, 39\% in Battambang, and $21 \%$ in Ratanakiri, while the use of seed from more than one type of seed source was uncommon at all sites $(4,0,2$, and $10 \%$ in Tay Ninh, Dak Lak, Battambang, and Ratanakiri, respectively).

Use of farm-saved seed in the low-intensity sites represented 74 and $86 \%$ of the total number of seed acquisitions in Ratanakiri and Dak Lak, respectively, and 64 and 32\% in the high-intensity sites of Battambang and Tay Ninh, respectively (Table 4). Sale was a more common mechanism of seed acquisition and provision at high-intensity production sites than at the low-intensity sites in both countries. Tay Ninh was the only site in which seed purchase was more frequent than use of farm-saved seed, with the major sale supply actors being traders, other farmers, and community root collection points (Figure 2). Within both highintensity sites, the majority of farmers' seed provisions to others were through sales (57\% of transactions in Battambang and $79 \%$ of transactions in Tay Ninh), while at low-intensity sites gifts remained dominant (54\% in Ratanakiri, 93\% in Dak Lak, Table 5). Figure 2 illustrates that stakes sold to others were mostly destined for traders in Tay Ninh, while in Battambang other farmers were the main purchasers.

Over all stake acquisitions recorded (omitting self-provided seed), the average numbers of stakes per acquisition were $6,265 \pm$ 5,132 in Battambang, 1,820 $\pm 2,542$ in Ratanakiri, 8,281 $\pm 12,201$ in Tay Ninh, and 2,719 \pm 1,794 in Dak Lak. Over all recorded stake provisions to others, the average numbers of stakes per provision were 5,289 $\pm 6,437$ in Battambang, 2,608 \pm 4,428 in Ratanakiri, 39,100 \pm 70,066 in Tay Ninh, and 3,312 \pm 4,816 in Dak Lak, respectively.

\section{Spatial Reach of Seed Networks Bi-National Survey}

Table 6 describes the geographic distances involved in recorded seed exchanges. In both countries, most seeds originated from within the commune; 71 and $90 \%$ of individual acquisitions in Cambodia and Vietnam, respectively. In farmer provision of stakes to others, 91 and $87 \%$ were within the commune in Cambodia and Vietnam, respectively.

In Cambodia international sources of seed were mentioned in 76 cases ( $20 \%$ of individual acquisitions), while no such cases were reported in Vietnam. These included imported seed into Cambodia, in descending order of frequency, from Vietnam, Thailand, and Laos. Acquisitions originating from other provinces within the country involved 2 and $4 \%$ of seed use in Cambodia and Vietnam. In Vietnam no farmers reported providing seed to buyers outside of the country, but $12 \%$ of seed provisions to others were instead reported as being to "unknown" destinations, with traders implicated as the buyers. Responses of "unknown" resulted from scenarios including purchase by an aggregator who intended to again resell stakes, sale to traders without specific premeditated resale sites, or in cases where the origin of the purchaser or destination of the planting material were simply not discussed or disclosed.

Due to the degree of uncertainty in locations of stake origin/destination, we were unable to calculate seed travel distances, and therefore report our results on the order of communes, districts, provinces and countries; all of which vary in size. However, the longest exchange distances observed were those between Vietnam and Cambodia's Western provinces (in particular Battambang, Banteay Meanchey, and Oddar 
TABLE 6 | Geography of stake exchange in the 2016 field season from both bi-national and subnational surveys, displayed in percentages of overall stake transactions recorded at each site, with $\mathrm{KH}$ indicating Cambodia and VN indicating Vietnam.

\begin{tabular}{|c|c|c|c|c|c|c|c|c|c|c|c|c|}
\hline \multirow[t]{4}{*}{ Source } & \multicolumn{4}{|c|}{ Bi-national survey } & \multicolumn{8}{|c|}{ Subnational survey } \\
\hline & & & & & \multicolumn{4}{|c|}{ High intensity } & \multicolumn{4}{|c|}{ Low intensity } \\
\hline & \multicolumn{2}{|c|}{$\mathbf{K H}$} & \multicolumn{2}{|c|}{ VN } & \multicolumn{2}{|c|}{ Battambang (KH) } & \multicolumn{2}{|c|}{ Tay Ninh (VN) } & \multicolumn{2}{|c|}{ Ratanakiri (KH) } & \multicolumn{2}{|c|}{ Dak Lak (VN) } \\
\hline & Ac. & P. & Ac. & P. & Ac. & P. & Ac. & P. & Ac. & P. & Ac. & P. \\
\hline Own field & 47 & & 64 & & 64 & & 30 & & 70 & & 86 & \\
\hline Same commune & 24 & 91 & 26 & 87 & 23 & 73 & 65 & 62 & 25 & 91 & 0 & 95 \\
\hline Other commune-same district & 4 & 2 & 2 & 0 & 3 & 8 & 3 & 10 & 1 & 2 & 0 & 1 \\
\hline Other district-same province & 2 & 4 & 3 & 2 & 5 & 8 & 0 & 0 & 1 & 0 & 0 & 0 \\
\hline Other province-same country & 2 & 3 & 5 & 0 & 4 & 8 & 0 & 0 & 2 & 2 & 7 & 0 \\
\hline Other country & 20 & 0 & 0 & 0 & 1 & 0 & 0 & 0 & 0 & 0 & 0 & 0 \\
\hline Unknown & 1 & 1 & 1 & 12 & 1 & 3 & 2 & 28 & 1 & 6 & 7 & 4 \\
\hline Total $n$ transactions & 381 & 130 & 234 & 104 & 118 & 37 & 105 & 29 & 147 & 54 & 97 & 73 \\
\hline Sample $n$ (individuals) & \multicolumn{2}{|c|}{240} & \multicolumn{2}{|c|}{206} & \multicolumn{2}{|c|}{100} & \multicolumn{2}{|c|}{100} & \multicolumn{2}{|c|}{100} & \multicolumn{2}{|c|}{94} \\
\hline
\end{tabular}

"Ac." denotes seed acquisition, while "P." denotes seed provision. Self-provisioning from the previous year is considered as one transaction.

Meanchey), all of which are between 250 and $350 \mathrm{~km}$ from the closest Vietnamese border crossing.

\section{Subnational Survey}

The majority of farmers both acquired and provided most stakes within their own communes: 86 and 73\% in Battambang, 97 and $62 \%$ in Tay Ninh, 95 and 91\% in Ratanakiri, and 86 and 95\% in Dak Lak, respectively.

In the low-intensity sites of Ratanakiri and Dak Lak, 91 and $95 \%$, respectively, of seed provisions to others were within the commune, and the absolute number of exchanges was higher than in high-intensity sites. At the high-intensity sites, only 73 and $62 \%$ of seed provisions remained within the commune in Battambang and Tay Ninh, respectively, with significant amounts of exchange taking place at higher geographic scales (Table 6).

In Tay Ninh $28 \%$ of stake provision transactions went to "unknown" destinations; far more than at the other three sites. Tay Ninh also received and provided a greater proportion of seed transactions in other communes within their district (3 and 10\%, respectively). The highest percentage of seed acquisition from other provinces within the same country was in Dak Lak (7\%).

\section{Bi-National Survey Seed Network Analysis}

Bi-national level survey data included 840 unique transactions (both seed acquisitions and provisions) recorded from 31 districts in 26 Cambodian and Vietnamese provinces in 2016. Cambodia exhibited a high degree of interprovincial exchange (Figure 3A), including non-monetary transactions and several cases of long-distance trade (e.g., between Oddar Meanchey and Stung Treng). By contrast, Vietnam exhibited less exchange overall, with exchanges often being barter-type transactions within provinces $(<10,000$ stakes per farmer, Figure 3A). Many Cambodian farmers reported receiving stakes internationally from Vietnam, Thailand, and in a single case Laos, although they were usually unable to provide a province of origin (Figure 3, gray dashed lines). Very large volumes of stakes ( $>10,000$ stakes per farmer in some cases) were exchanged between five of the surveyed provinces (Battambang, Pailin, Banteay Meanchey, Tay Ninh, and Tboung Khmum). All of these provinces, with the exception of Tay Ninh, are in Cambodia. Battambang, Pailin, and Banteay Meanchey are all adjacent provinces abutting Cambodia-Thai border in Northwest Cambodia, while Tboung Khmum and Tay Ninh are neighboring provinces on either side of the Cambodia-Vietnam border.

Node degree is a measure of the number of links a given node has with others in the network (in our case, the number of transactions, Pautasso, 2015). In the provincial exchange network, the Cambodian province of Battambang had the highest node degree (6), with connections to several other Cambodian provinces, as well as traders in Thailand and Vietnam. Battambang also had the highest eigenvector centrality, meaning that it is not only highly connected, but also connected to other highly connected neighbors. This may in part be driven by the comparatively large area of cassava in Cambodia's Northwestern provinces. Node strength is a measure of the sum of the link weights, in this case the aggregated number of stakes exchanged (Hernandez Nopsa et al., 2015). Battambang also exhibited both the highest node in- and outstrength, importing only a slightly higher number of stakes than were exported (Figure 3B). The Cambodian provinces of Pailin, Kampong Thom, and Oddar Meanchey also had similar hubnode properties. From the data captured in this survey, provinces were characterized as net-importers or exporters based on their node-strength (Figure 3B). It is important to note that it was difficult to capture exchanges mediated by traders. For example, a large number of transactions involved traders in Tay Ninh (Table 4) in which the final destinations of seeds were unknown (Table 6), meaning that the respondent did not even know which country seeds were destined for, and these transactions are therefore not represented in the final figure (Figure 3B). This limitation seriously underrepresents the significant role of Tay Ninh as an exporter of seed to Cambodia and other Southern Vietnamese provinces. 

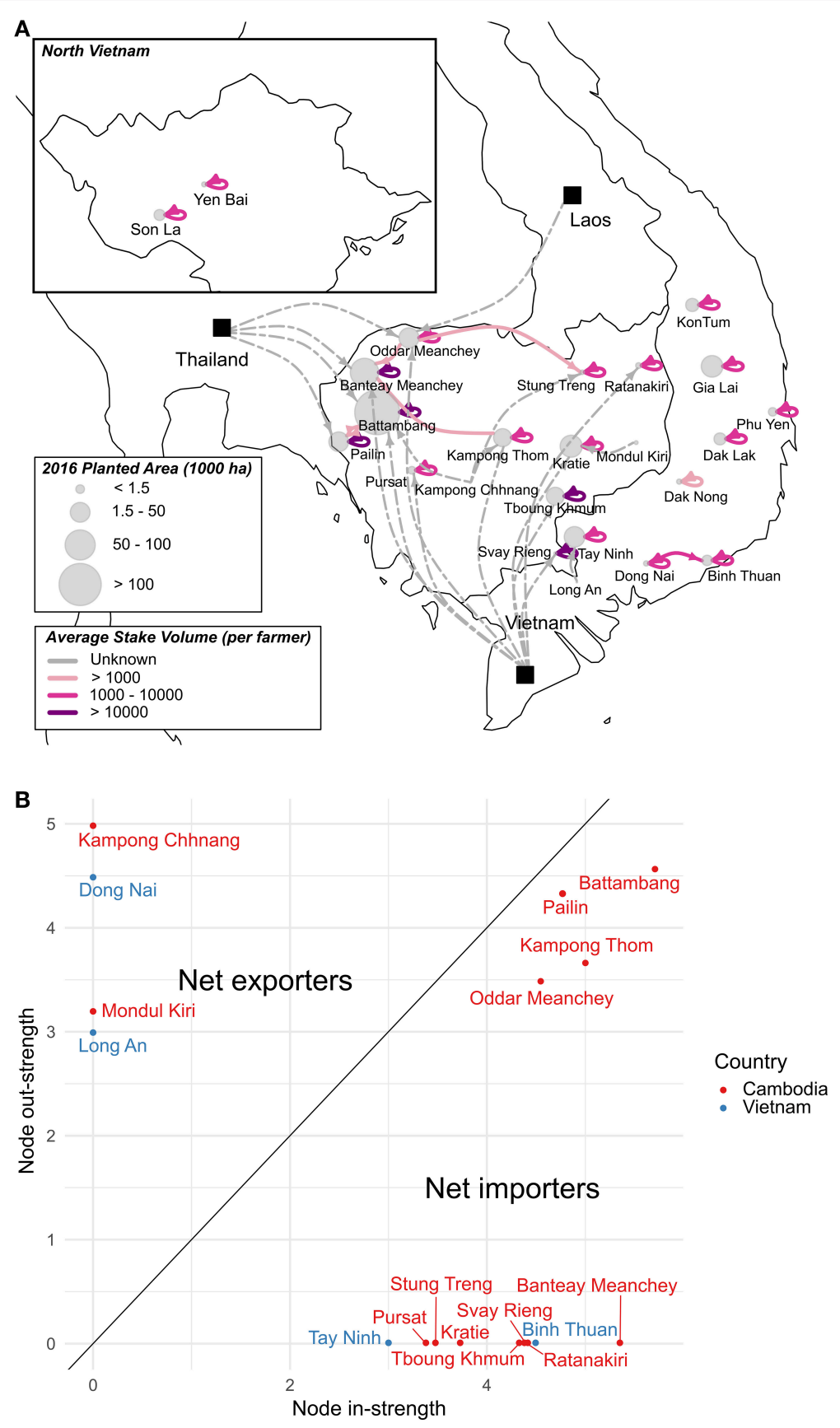

FIGURE 3 | (A) Network graph representing stake exchange per surveyed farmer (links) between provinces (nodes) in 2016, aggregated from national-level survey of farmers $(n=240)$ in 16 districts in Cambodia, and 15 districts in Vietnam $(n=206)$. The inset map area represents Northern Vietnam. Self-loops indicate provisions that occurred within a given province. Link color represents volume of stakes exchanged, corrected by number of farmers surveyed (stakes exchange per farmer). Gray hashed links reflect instances of stake transactions from unsurveyed regions, where there was no formal sampling effort. Node size represents provincial cassava planted area in 2016 (ha). Black, square nodes represent stake movements where country, but not province name was provided by survey respondents. Note that the only stake movement data for Thailand and Laos were those mentioned by Cambodian and Vietnamese respondents. Links listed with "unknown" destinations or origins are not illustrated. Because high-production districts within provinces were targeted for this survey, volumes of seed exchange should be considered the upper-end of the likely province-wide average stake exchanges per farmer. (B) Log10-transformed node strength, the weight of links (in this case, number of stakes per farmer), by province. In-strength is the number of incoming stakes, out-strength is the number of outgoing stakes. Provinces above the bisectrix can be considered net-exporters, while provinces below the bisectrix represent net-importers. 


\section{Planting Material Handling and Quality}

Planting stakes are stored in bundles of 15-25, kept either in the open field or underneath trees on the field borders. Formal seed production, certification, and marketing are virtually nonexistent in this region. The percentages of respondents applying chemical treatments to their stakes prior to planting were 20 and $24 \%$ in the high-intensity production sites of Battambang and Tay Ninh, respectively, and 76 and $30 \%$ in the lowintensity sites of Ratanakiri and Dak Lak, respectively. At both Vietnamese sites the most common practice mentioned was use of a chemical product bath shortly before planting the stakes, while in Cambodia applying a chemical product during storage or using a combination of both practices was more common.

Loss of stake viability during storage occurred in 85 and $80 \%$ of households in Battambang and Ratanakiri, with loss estimates of 27 and 32\% of stored seed, respectively. In Vietnam, loss of seed viability during storage occurred in 32 and $64 \%$ of households in Tay Ninh and Dak Lak, with loss estimates of 25 and $27 \%$ of stored seed, respectively.

Over all 1,462 seed transactions recorded in both surveys, only $1 \%$ of transactions were rated by farmers as containing poor quality stakes. At the national level, most farmers in Cambodia and Vietnam considered that the stakes they acquired were of good or average quality ( 67 vs. $30 \%$ and 82 vs. $18 \%$, respectively), and that planting materials they provided to others were of good and average quality ( 85 vs. $15 \%$ and 66 vs. $32 \%$, respectively, with a further $2 \%$ reported as poor quality in Vietnam). Quality is a subjective measure, and farmer perceptions in the present study were related to a variety of quality indicators, including, in descending order of importance, number, and density of nodes (i.e., axillary bud/leaf scar), stake size, age/freshness of planting materials, pest and disease symptoms, and a handful of other characteristics (Figure 4). Number/density of nodes, followed by size of stakes, were the most commonly mentioned indicator of quality at all of the subnational sites except Dak Lak, in which the order was reversed. Freshness/age of stakes and signs of pest and disease were the third and fourth most commonly mentioned quality indicators.

\section{Traders}

In the vast majority of cases farmers indicated that they did not have contact information to reach stake traders, frequently stating that they were not based in the community. Tay Ninh, the province with the highest number of cassava processing factories in Southeast Asia, was the exception to this rule, identifying interactions with over 30 individual traders in the 2016-2017 season. Only a small number of traders were successfully contacted and interviewed in Tay Ninh $(n=12)$, and Dak Lak ( $n$ $=7$ ), while in Cambodia only a single trader was contacted; the sole trader serving the study commune in Ratanakiri province. Consequently the traders who were interviewed were also typically those who were based in the communities. In Cambodia, the single trader contacted was a female shop owner who had bought stakes from neighboring Kampong Cham province, but noted that the stakes had first entered Cambodia via another trader from Vietnam.

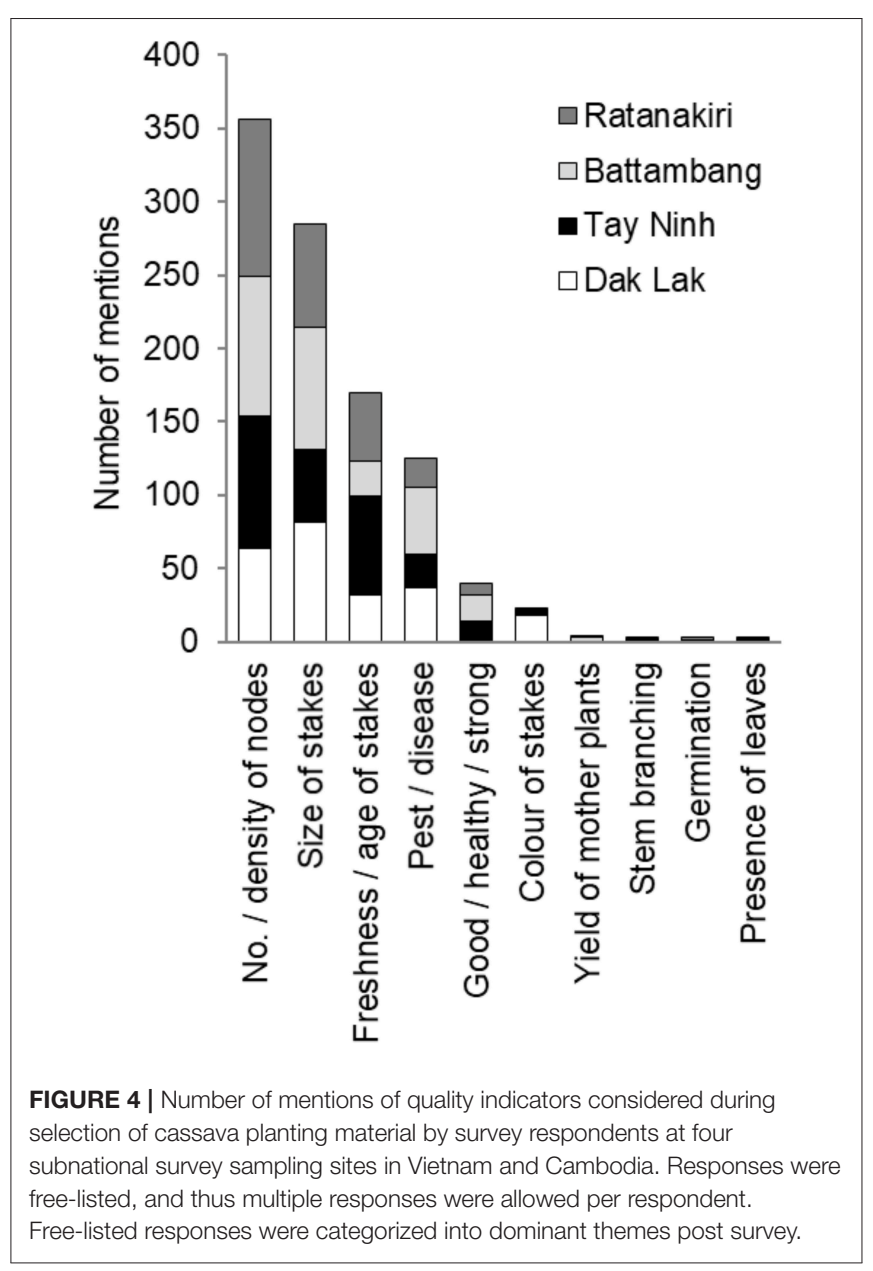

In Tay Ninh, all traders interviewed were male, although in two cases the respondents indicated that their wives also participated in the business of stake trade. In Dak Lak, two of the seven traders were female. In Tay Ninh all traders indicated also farming cassava themselves, while 10 of the 12 additionally traded fresh roots; however all traders listed stake trading as their main economic activity. This contrasted sharply with Dak Lak, where six of the seven also traded fresh roots, four listed stake trading as their main activity, and only two of the seven traders were engaged in farming themselves. None of the traders in Tay Ninh reported supplying credit services to their customers, while conversely all of the traders in Dak Lak reported that they did.

All traders in Dak Lak acquired their stakes from a single source in the survey year, except one who listed two sources, and all of the suppliers of stakes were farmers that the trader knew personally. In Tay Ninh all traders purchased from multiple sources, with one trader reporting eight different sources within the single season. All traders mixed stakes together when they acquired them from multiple sources.

Traders from Tay Ninh reported selling to 15-20 farmers in the previous season, while those from Dak Lak served from 20 to 120 farmers. Six of the 12 traders from Tay Ninh indicated that they traded stakes into Cambodia themselves, or sold stakes at the 
Chang Riec border gate into Cambodia, while the remainder of their sales were within Tay Ninh province. By contrast, all stakes sold by the traders in Dak Lak originated in Tay Ninh province. Traders operating in Dak Lak all sold within their own province, with the exception of one who sold to two neighboring provinces, and another who sold to Cambodia.

\section{DISCUSSION}

\section{Seed System Actors in Cambodia and Vietnam}

Our evaluation of the constituents and character of Cambodia and Vietnam's cassava seed systems in the present study was limited by our sample selection, which favored important cassava-producing regions of both countries, and our results should be interpreted in that light. Similarly, due to the relative paucity of systematic research on the topic in Southeast Asia, many of the comparative studies contextualizing our findings are drawn from outside of the region. Our study provides a first situational analysis of the cassava seed systems in Cambodia and Vietnam.

Cassava seed systems in both Cambodia and Vietnam were clearly predominantly farmer-led, with formal actors and marketing structures rarely mentioned. Prevalent use of selfsupplied seed, pronounced reliance on social networks for exchange, and a near absence of agro-dealers in the supply chain are common in vegetatively propagated crops (McGuire and Sperling, 2016). Government participation was rare in our study, and we found no involvement of the NGO or relief programs found in other developing country contexts (e.g., Longley and Sperling, 2002; Dyer et al., 2011; Legg et al., 2014; Christinck et al., 2018). Private sector involvement was modest and localized; agro input dealers were involved in seed supply at the Vietnamese national level (6\% of seed use), a local starch factory contributed in Dak Lak (4\% of seed use), and community-based cassava root collection businesses were important suppliers in Tay Ninh (13\% of seed use). Private sector involvement was even rarer in Cambodia, with isolated mentions of participation of starch factories or market sellers. A similar lack of formal marketing structures was described in Amazonian cassava seed systems, where local exchange of planting materials through gifts among kin groups dominated seed exchange (Elias et al., 2000; Coomes, 2010), with preferential exchange dynamics among different kin groups and within households (Delêtre et al., 2011; Violon et al., 2016).

Social relationships and norms influence the exchange of seed at local scales (McGuire, 2008; Thomas and Caillon, 2016), and implications for social prestige related to providing or receiving seed may modify exchange patterns. The most important exchange actors in our study were friends, neighbors, and relatives, however provision of seed to strangers approached a fifth of all seed provisions in Cambodia. Farmers provided seeds to strangers at all of the subnational sites, but only reported acquiring seeds from a stranger themselves in Tay Ninh (2\% of seed use cases). In addition, Table 5 demonstrates an imbalance between giving and receiving transactions. Coomes (2010) noted that cassava producers in Peru consistently better remembered who they had acquired seed stock from than who they had given it to, while in other cases farmers have been noted to be reluctant to "beg" for seed from their neighbors (Samberg et al., 2013). The role of seed in social standing may have similarly influenced our respondents. In addition, the sampling methods of this study selected nationally important cassava-growing areas in each country. Provisions of seed to others also involved recipients from outside the community. Cassava producers operating on the fringes of developed cassava production regions may exhibit different seed exchange patterns, such as less ready access to sources of seed, leading them to seek seed from more established production areas. Further research is required to understand seed networks in areas where cassava is a less major crop.

Traders were important providers of seed to farmers in both countries, and buyers of seed in Vietnam ( $9 \%$ of national sales, $69 \%$ in Tay Ninh), mediating seed exchanges over distances up to several hundred kilometers, in large volumes requiring coordinated logistics. The inability of survey teams to reach all but a single trader listed by Cambodian farmers for follow-up interview is a reflection of the highly mobile and seasonal character of trading activities, similar difficulties to those documented in interviewing sweet potato vine traders in Uganda (Rachkara et al., 2017). Traders in Vietnam's Dak Lak and Tay Ninh provinces had different business models. Only a third of Dak Lak's traders were farmers themselves, half viewed cassava seed trading as their main business, and all offered diversified services (such as supplying credit and trading fresh roots). Tay Ninh's stake traders, all themselves farmers based in the community, listed stake trading as their main business. These differences also have impacts on relationships and trust with clients. Traders operate in ever more precarious legal spaces (Wattnem, 2016), and their interactions with farmers take many forms, from systematic and recurrent to intermittent and opportunistic. The roles of cassava seed traders across different contexts remain poorly characterized, and the findings of the present study suggest their importance in connecting spatially disparate local seed networks, and the urgent need for further research elucidating trader activities and practices.

\section{Existing Seed Networks at Multiple Scales National and Regional Scales}

Farmer reliance on self-saved seed, frequent exchange within local communities, and facilitation of long-distance exchanges through traders depict a combination of self-contained seed reproduction, extensive decentralized short distance exchanges through commune-level interactions (including both financial and social motivators), and inter-provincial/international connectivity and exchange driven by farmer demand for seed, and industry demand for roots. This system is shaped at the regional level by a source-sink relationship between Vietnam/Thailand and Cambodia, and is likely facilitated by existing commodity transport networks.

The exclusive use of self-saved seed (39 and 63\% in Cambodia and Vietnam, respectively), was less than that reported in other contexts with commercial value chain-linked production [83\% of cassava producers across 12 Caribbean countries (Ospina et al., 
2016)]. Farmer-to-farmer seed exchange in both Vietnam and Cambodia supported decentralized distribution of stakes, with approximately a quarter of seed acquisitions and 91 and $87 \%$ of seed provision to others occurring within the respondents' own communes in Cambodia and Vietnam, respectively. The motivations and environmental and social factors influencing decision-making at the household and commune scales merit further inquiry.

Transactions between districts and provinces occurred at lower levels $(\leq 5 \%)$, typically involving trader intermediaries. Inter-province exchange was relatively uncommon in Vietnam, with transactions recorded between only a few sets of Southern neighboring provinces. Province-province exchanges were more frequent in Cambodia, especially involving the Northwest provinces of Banteay Meanchey, Oddar Meanchey, Pailin, and Battambang, Cambodia's major cassava production belt. Tay Ninh in particular played a key role in export of planting material via traders, although many of these exchanges are not represented in our network analysis due to their origins and/or destinations being unknown to the farmer respondents. These unknown interactions reached $12 \%$ of seed provisions by Vietnamese farmers to others through traders or village root collection points. Our province-province exchange network thus likely underestimates actual exchange at larger scales typically requiring trader mediation.

On a regional level, movements of large quantities of seed from Vietnam and Thailand into Cambodia are regular, involve volumes reaching millions of stakes per season, and mirror industrial root transport. Cambodia was a net sink of seed, recording no outgoing international trade. Stakes from Vietnam were imported to nine different Cambodian provinces, including those near to the Vietnamese border and also Cambodia's Northwestern provinces, $>250 \mathrm{~km}$ away. In addition to significant trans-border exchange, all trader respondents interviewed in Dak Lak reported obtaining their seeds from Tay Ninh, suggesting further inter-province trader movement in Vietnam not recorded in our farmer surveys due to the limitations of our sampling design.

Drivers of seed exchange at the inter-provincial and regional scales include cassava cropping area expansion, and the availability of inexpensive back freight shipping from cassava root and chip trading networks. These effectively subsidize longdistance transport in a mirror image of root flows to Vietnam and Thailand's processing centers. The department of agriculture and rural development (DARD) of Tay Ninh has identified 68 cassava processing factories in Tay Ninh province with a capacity of 166,000 tons per month, drawing on fresh root supply from a large surrounding area in both Vietnam and Cambodia (DARD, 2018). DARD estimates 3.5 million tons of fresh roots were processed in these factories in 2017, of which 1.6 million tons originated in Cambodia, presenting an enormous annual flow of trucks with back freight potential for seed transport.

Southeast Asia's climatic heterogeneity is an additional driver for regional stake exchange. In Vietnam's Northern highlands, cold, wet winters constrain production to $\sim 10$ months of the year, while Southern Vietnam's more regularly distributed temperature and rainfall patterns permit staggered planting.
Northwest Cambodia's hot, dry cassava production belt faces important losses of seed viability from premature sprouting or desiccation during the $\sim 3$ month dry season. Stakes stored for 90 days under similar conditions in central Thailand suffered germination losses of $71 \%$ under full sun, and $56 \%$ stored under shade (Sinthuprama and Tiraporn, 1986). In the present study, seed loss was experienced by $80-85 \%$ of Cambodian respondents in the subnational survey; far more than in Vietnam (32 and 64\% in Tay Ninh and Dak Lak, respectively). In Indochina, processing factories frequently offer higher prices for off-peak root supply, incentivizing early harvest, and further extending stake storage times (and hence losses). When chip markets are involved, sufficient time is needed for chopping roots (often done manually) and sun drying chips, similarly extending storage times.

\section{Low-Intensity Sites}

Ratanakiri, the lowest production intensity site in the study, was isolated from seed exchange with other provinces, with only a single resident trader. The large imports of stakes from Vietnam detected in the bi-national survey were not replicated in the subnational survey, in which only $2 \%$ of seed purchases were reported from traders, highlighting the variability at different locations within a single province or district. Fine-scale factors such as proximity to major root product transport routes may greatly influence the frequency of chance interactions with transient traders.

Vietnam's low-intensity site, Dak Lak, was the most farmerdominated exchange system of the four case studies. The use of farm-saved seed was prevalent $(86 \%)$, and the site had the highest absolute incidences of provision of seeds to others ( $n$ $=73$ ). These were almost exclusively through gifts, and $96 \%$ of the recipients of these interactions were other farmers. Dak Lak alone listed loans/credit as methods of acquisition and provision of stakes, and mentioned a diverse range of actors, including local government and a starch factory, as sources of stakes. Trader interactions were rare in the subnational survey ( 2 and $1 \%$ of acquisitions and transactions, respectively), and in the results of the bi-national survey Dak Lak is isolated from the remainder of the network but exhibits significant intra-province exchange. However, interviews with local traders indicated frequent importation of seed from Tay Ninh province. Low-intensity sites also harbored the highest rates of accessing multiple seed sources, particularly reliance on self-saved seed and seed from acquaintances within the community (Figure 2). Provisions of seed to others, mostly farmers within the community, were also more common at these sites.

\section{High-Intensity Sites}

Sales of seed were more important components of both acquisition and provision at high-intensity sites than their lowintensity counterparts. Seed provisions from high-intensity sites were primarily sales, while at low-intensity sites gifts were most important. Average volumes of stakes per provision at highintensity sites were 2.0 times greater in Cambodia and 11.8 times greater in Vietnam than at low-intensity sites. High-intensity production sites had on average 1.4 and 2.7 times the area 
of cassava per household as their low-intensity counterparts in Cambodia and Vietnam, respectively, yet also recorded far fewer stake provisions to others. When they did provide planting materials to others, farmers in high-intensity production sites were more likely to engage in high-volume sales, and a lower percentage of exchanges were within the commune compared to low-intensity sites (Figure 2). These trends suggest a commodification of seed supply in higher production intensity environments, where financial incentives drive high-volume, longer-distance transactions mediated by trader agents or larger landholders.

Battambang, Cambodia's largest cassava producer in 2016, recorded the highest volumes of seed movement in our study, with flows exceeding 100,000 stakes from both Thailand and Vietnam. Trade with neighboring Cambodian provinces of Kampong Chhnang, Pailin, and a large volume of intraprovincial exchanges exceeding 1 million stakes were reported. The demands of Thai and Vietnamese processing markets have led many farmers to adopt early harvesting practices due to favorable off-peak prices, extending the operational season of starch processing facilities. Battambang exhibited high rates of stake purchase over the previous three seasons $(22-30 \%$ of respondents), paying the highest amount on average for seed from 2014 to 2016, and engaging in an abundance of economic seed transactions. This led to its high connectivity in the trade network on the regional scale (Figures 3A,B), including a small number of transactions attaining $~ 300$ kilometers from Vietnam into Western Cambodia.

As a province, Tay Ninh appeared largely self-contained in terms of stake exchange. As the subnational survey would reveal, this masked the large quantity of transactions with "unknown" destinations brokered by the province's extensive trader network, and a large quantity of stakes imported into Cambodia likely originate there. Over 30 individual traders were listed by Tay Ninh's 100 respondents, and Tay Ninh displayed the highest rates of stake purchase (33-63\% of respondents from 2014 to 2016). In addition, $55 \%$ of seed used in the study year was purchased, and only $11 \%$ of respondents indicated planning to save their stakes for the coming season. Trader supply and purchase of stakes exceeded that of any other external actor, unique among sites in our study (Figure 2). Many farmers acquired new stakes annually from a trader in pre-arrangements in which the trader supplied quality seed, and farmers reciprocated harvest rights to their mature fields (including both roots and stems). By this arrangement, farmers avoided the labor and logistic complications of harvesting and storing large amounts of perishable planting materials. Trust-based relationships between farmers and seed traders are critical in both formal and informal seed networks (Lyon, 2000; Bentley et al., 2011), and merit further study in Southeast Asian cassava systems.

\section{Varietal Diversity}

Our survey found low varietal diversity, with a range of 14 varieties (avg. 1.38 in Cambodia, 1.09 in Vietnam). Similar recent findings have been reported from neighboring Thailand, where a study of 80 farms reported that 51 grew $\geq 2$ varieties, while only 14 grew $\geq 3$ varieties; nearly all of which were modern elite genetic lines (Fu et al., 2014). Maintenance of varietal diversity may reflect differences in traditional knowledge, heritage, and management (Pinton, 2003), as demonstrated by Amazonian on-farm diversity ranging from 1 to 8 cultivars per household (avg. 3.5, Kawa et al., 2013), to 66 traditional varieties between five female farmers (Emperaire et al., 1998). Cassava's role as a traditional staple in the Amazon contrasts starkly with its relatively recent introduction as a cash crop in Southeast Asia and accompanying distribution of industrial varieties originating from local breeding programs. Near exclusive focus on productivity may lead to decreased diversity in increasingly commercial production schemes (Salick et al., 1997), a trend observed in many crops experiencing increased market integration (Tripp, 1994; Van Dusen and Taylor, 2005). However, maintenance of crop genetic resources also plays a role in the ability of farmers to adapt to environmental and market uncertainty (Almekinders and Louwaars, 2002, and references therein), which may suggest why Cambodian farmers reported higher varietal diversity than their Vietnamese counterparts in both the bi-national and subnational surveys.

Varietal identity in our study was based on farmer perceptions, and not confirmed genetically. Cassava varietal identification is challenging for several reasons, including morphological differences resulting from genetic $\times$ environment interactions (Floro et al., 2018), and inconsistent naming including the use of non-standard local names (Sardos et al., 2008; Rabbi et al., 2015), which may lead to high rates of misidentification (Floro et al., 2018). The mixing of several different stake sources by all traders interviewed likewise suggests that single fields planted with varietal mixes may be common, with unknown effects on exchange behavior.

\section{Strengths and Weaknesses of Existing Cassava Seed Systems}

Shaw and Pautasso (2014) have highlighted the "tension" between free movement of goods (usually considered beneficial; for example new varieties) and free movement of pathogens (detrimental) along the same pathways in plant disease pathosystems. In other words, highly efficient dissemination networks can translate to equal efficiency in the spread of pests and disease (Shaw and Pautasso, 2014; Patil et al., 2015). Depending on the perspective of each actor, given properties of the seed system can often simultaneously be viewed positively or negatively. Informal networks efficiently disseminate the seeds of many crops, including cassava, in diverse contexts (Dyer et al., 2011; Fu et al., 2014; Coomes et al., 2015). Our findings provide a further example of an informal, yet effective, seed network serving a wide range of farmers, the existence of which had long been suggested by the widespread, spontaneous appearance of Thai and Vietnamese elite cassava varieties across Cambodia (Howeler and Ceballos, 2006).

Trade network structure plays a significant role in plant health epidemics (Moslonka-Lefebvre et al., 2011; Shaw and Pautasso, 2014; Hernandez Nopsa et al., 2015). Even in our single year sample, traders mediated exchanges over a scale of several hundred kilometers. Such networks have 
powerful reach for scaling uptake and dissemination of introduced germplasm, and potentially knowledge products and extension information, throughout the seed networkbut only if actors who leverage trust and social capital are fully engaged. A core strength of informal seed systems, and simultaneous challenge to interventions in their functioning, is the deeply social character and abundance of trust-based interactions. The importance of personal acquaintances in the present study was complimented by the participation of strangers, especially unacquainted farmers and mobile stake traders. Traders' key roles in connectivity of the seed network may either be highly dependent on social relationships and trust (as in Tay Ninh), or purely opportunistic encounters (as in Ratanakiri). Traders therefore assume great importance in seed quality control. Recurrent, reciprocal relationships as described in Tay Ninh may serve as models for the development of acceptable QDS supply to other areas. However, the aforementioned practice of traders mixing stakes from different sources may both compromise varietal purity, and increase the potential distribution of infected materials.

In addition to a nearly contiguous cassava production landscape, low crop diversification, low cassava varietal diversity, and frequent off-farm seed exchange increase vulnerability to the spread of pests and diseases. Cassava's lignified outer stem tissues do not exhibit obvious symptoms for a wide range of pathogens (Lozano et al., 1981), complicating diagnosis once stakes have been harvested from the mother plant, and thus separated from foliar and root symptoms.

Patterns of existing stake acquisition, especially purchase, observed in this study suggest the potential for demanddriven markets for quality seed, but these currently represent $<0.1 \%$ of national stake supply in Cambodia and Vietnam. The absence of certification schemes or quality-declared systems in both Vietnam and Cambodia mean there are currently no available sources for guaranteed clean material for the vast majority of farmers. In the absence of certification and phytosanitary screening mechanisms, farmers at the four subnational sites evaluated planting material quality based on traits associated with germination rather than pest or disease.

The legislative environment for cassava seed systems will play an important role in the development of formal systems as well as interventions into various aspects of informal systems. In Cambodia and Vietnam, the basic policy instruments to guide the development of formal seed systems are in place (Table 7). These include delegation of responsibilities for various aspects of seed production and certification to organizations, and distinction of recognized seed certification classes. However, regulations are not commonly applied to cassava seed production, distribution, and reuse of planting materials, all of which predominantly occur outside the sphere of formal seed systems. Legislation is more consistently applied to rice, maize, and commercial vegetable seed value chains, and generally lacks implementation on vegetatively propagated crops such as cassava. Nevertheless, policies and legislation surrounding cassava seed use will be integral in shaping future policies and projects for preventing and controlling disease spread in cassava seed systems.

\section{Key Entry Points for Seed Systems Interventions}

In light of emerging phytosanitary constraints in Southeast Asia, our findings indicate several aspects of existing seed systems which require urgent intervention. Conceptions of formal and informal seed systems are not antithetical, but rather possess complementary strengths and weaknesses with potential synergies (Almekinders and Louwaars, 2002). Seed systems are not binary, but span a complex range of elements combining into adapted, functional systems driven by the changing needs and demands of stakeholders. Interventions should therefore attempt to build systematically on the strengths of existing seed systems wherever possible to maximize impact. Several key interventions are suggested for Vietnam and Cambodia's cassava seed systems based on the results of the present study.

\section{Improving Farmer Seed Production and Selection Practices}

The dominance of farm-saved seed and farmer-to-farmer exchange in our study starkly contrasted with low levels of awareness of pest and disease, and few strategies in place to ensure farmer access to quality seed and prevent exchange of infected materials. Education campaigns should promote improved seed production practices at the farm level to reduce seed degeneration rates and eliminate the re-use or exchange of contaminated stakes. The importance of neighbors as seed suppliers in the present study underscores the need for mass outreach promoting practical approaches which can help to reduce disease pressures; for example positive and negative selection have been shown to increase root yields in susceptible cultivars under cassava mosaic disease pressure (Mallowa et al., 2006). Because labor shortages and large field sizes often limit the practice of roguing or seed selection, the concept of the "corner of prosperity" provides an important alternative. By partitioning an area of the farmer's field ( $10 \%$ is sufficient for own re-use) differential management may be applied for the production of high quality stems (Ceballos and Hershey, 2017). This strategy has potential for significant impact in areas where use of self-saved seed dominates. Farmer-based associations, not mentioned by respondents in the current study, could also become key actors in cassava stake production in Vietnam and Cambodia's decentralized intra-commune exchange systems through schemes such as multiplication and sale of QDS at the local level (Legg et al., 2014).

\section{Combining Seed Network Analysis With Surveillance and Biophysical Models}

The structure and function of seed networks can inform strategies for using observed pathogen distribution and incidence records to target sampling and mitigation efforts to the most effective actors and locations (Chadès et al., 2011; Sutrave et al., 2012; Hernandez Nopsa et al., 2015; Buddenhagen et al., 2017; Andersen et al., 2018). Network analysis enables modeling of likely origins and the anticipated movement of 
TABLE 7 | Summary of seed policy frameworks of Vietnam and Cambodia (2017).

\begin{tabular}{|c|c|c|}
\hline Country & Vietnam & Cambodia \\
\hline Key authorities & $\begin{array}{l}\text { - National level: Ministry of Agriculture and Rural Development (MARD) } \\
\text { - Provincial level: Department of Agricultural and Rural Development } \\
\text { (DARD) } \\
\text { - District level: Sub-MARD } \\
\text { - Department of Crop Production (DCP): quality control of commercial } \\
\text { seed (public and private) } \\
\text { - National Center for Variety Evaluation and Seed Certification } \\
\text { (NCVESC): organizes testing of new varieties and conducts seed } \\
\text { quality certification of crop seeds } \\
\text { - Department of Plant Protection (PPD): managing pests and diseases } \\
\text { of crops, monitoring health of imported seeds, pathology } \\
\text { - New varieties issued from: MARD, the Ministry of Education and } \\
\text { Training (MET), and private seed companies }\end{array}$ & $\begin{array}{l}\text { - National level: Ministry of Agriculture, Forestry and Fisheries } \\
\text { - ThAFF) and General directorate of agriculture (GDA) } \\
\text { Institute (CARDI) } \\
\text { - Seed law implementation, including development of related } \\
\text { articles-MAFF/GDA } \\
\text { - MAFF is responsible for seed testing } \\
\text { - Ownership rights of new seeds are certified by MIME after } \\
\text { all technical tests are completed and officially approved by } \\
\text { MAFF } \\
\text { - Registration of seed companies is done by the Ministry of } \\
\text { Commerce } \\
\text { - Registration of seed associations is done by the Ministry of } \\
\text { Interior } \\
\text { - Registration of community seed based organizations is } \\
\text { done by MAFF }\end{array}$ \\
\hline Key legislation & $\begin{array}{l}\text { - Ordinance on Plant Varieties (2004) } \\
\text { - Law on intellectual property (50/2005/QH11) } \\
\text { - Amendment of Intellectual Property Law (2009) } \\
\text { - Decree No. 07/CP (1996) } \\
\text { - Decree No. 88/2010/ND-CP } \\
\text { - Decree No. 187/2013/ND-CP } \\
\text { - MARD decision-35/2008; to legalize and stimulate farmer individuals, } \\
\text { groups, clubs, and cooperatives who and which can do breeding, } \\
\text { selection, seed production for household use and seed exchange } \\
\text { and supply in the market } \\
\text { - Joined (UPOV, 1991) in 2006 } \\
\text { - MARD circular 11/2013/TT-BNNPTNT; applies legislation governing } \\
\text { breeders' rights to 21 vegetatively propagated crops (no. } 16 \text { Manihot } \\
\text { esculenta Crantz) }\end{array}$ & $\begin{array}{l}\text { - Law on seed management and plant breeder's rights (2008) } \\
\text { - Sub-decree 69; identified as Legal Framework for } \\
\text { Agricultural Materials and Products } \\
\text { - Sub-decree } 15 \text { on phytosanitary inspection } \\
\text { - Sub-decree } 118 \text { assigned responsibilities for seed } \\
\text { management to the GDA under the MAFF } \\
\text { - Working with UPOV for development of seed laws, but not } \\
\text { yet a signatory of the convention }\end{array}$ \\
\hline Seed certification classes & $\begin{array}{l}\text { - Breeder seed (author's seed): the author(s) has/have selected, } \\
\text { crossbred or taken from the gene fund with stable heredity } \\
\text { - Foundation seed: produced from breeder seed with strict processes } \\
\text { for production, and quality standards stipulated by the State } \\
\text { - Certified seed (commercial seed): one of the last generations of } \\
\text { foundation seed, used for large-scale production but not kept as } \\
\text { seed } \\
\text { - Local seed: existed in a locality for a long time in a stable manner, } \\
\text { with heritable properties, and distinctive features }\end{array}$ & $\begin{array}{l}\text { - Breeder seed: produced by plant breeders in a single } \\
\text { - Frogeny selection approach } \\
\text { - Foundation seed: the most closely controlled class, grown } \\
\text { - Registered seed: grown from foundation seed; is a } \\
\text { multiplication class of seed with standards less strict than } \\
\text { foundation class } \\
\text { - Certified seed (commercial seed): progeny of registered } \\
\text { seed, using standards less stringent than registered seed }\end{array}$ \\
\hline
\end{tabular}

${ }^{a}$ GDA (General Directorate of Agriculture, Ministry of Agriculture Forestry and Fisheries), Kingdom of Cambodia.

detected pathogens, while a more complete representation of the entire network can also provide predictions of potential multi-step paths through the system. Anticipating multiple steps can be important when cryptic symptoms and long latent periods complicate immediate detection of a pathogen, such that detection may imply that the pathogen has already spread further. Before a pathogen has been detected in a region, the structure of a network suggests the most important locations to detect a new invasion. After a pathogen has been detected in particular locations, the structure of the network indicates other priorities for sampling "upstream" and "downstream" from the detection locations. Nodes in seed networks which are important hubs (having many links) or bridges (linking otherwise separate locations) for the spread of pathogens are likely priorities for both sampling and mitigation. Locations that are not hubs or bridges may still be at high risk for infection, if they are close to such nodes in the network.
Cambodia's Northwestern provinces are a growing, highly connected cluster with distant incoming links, and should receive focused attention for monitoring and containment. The highintensity production areas of Southern Vietnam are home to a well-developed trader network with a corresponding risk of rapid spread, and should similarly be a focus for preventative measures, dissemination of mitigation strategies, and eventually the release of resistant varieties.

Risk assessment is strengthened by incorporating other important risk factors, such as weather conduciveness to disease and pest reproduction. In contrast to Northwestern Cambodia, Vietnam's Northern provinces are relatively isolated, in combination with low suitability for key pests including the cassava mealybug (Phenacoccus manihoti, Yonow et al., 2017), and the insect vector of SLCMV, the whitefly B. tabaci (Campo et al., 2011). The combination of limited regional network connectivity, low potential for B. tabaci, and the current 
absence of the SLCMV virus suggest the potential for the North's $>100,000$ ha of cassava to provide low pathogen risk stake multiplication.

\section{Integrating Clean Seed Production Schemes With Informal Seed Networks}

As phytosanitary pressures on cassava increase (Graziosi et al., 2016), formal "clean seed" initiatives have already begun to emerge in Southeast Asia. Formal production pipelines are often linked to public breeding programs or specific projects, and monitor quality in terms of varietal purity, disease control, and physiological age. Fostering resilience in cassava seed systems will require cooperation with traders to bridge formal and informal systems (McGuire and Sperling, 2013), and to expand the reach of clean seed initiatives, extension, and disease monitoring. Links between the existing seed system and crop breeding networks which can supply sources of resistance will also prove important for long-term pathogen management (Garrett et al., 2017).

Facilitating these interactions will require some acknowledgment of the large international trade pathways of cassava seed in Southeast Asia. Considering industry's central role in root trade and the reciprocal activity of root and seed movement, increased involvement of private sector actors, including root processing factories and purchase points, could be impactful in promoting and scaling the use of quality seed. Organizations of cassava processors and industry members exist both in Thailand and Vietnam, and in the former are already engaged in domestic seed multiplication. These existing operational models should be further studied and lessons drawn from their experiences.

Seed regulations are often designed with commercial systems in mind (Spielman and Kennedy, 2016), and when applied to informal seed systems may discourage transparency. Engaging with informal seed networks from an exclusively punitive legislative perspective would prove counterproductive (Wattnem, 2016). Institutional innovations such as seed clubs in Vietnam have led to an official recognition of the role of farmers in the seed system by the government through "socialization in seed production and supply" in the rice sector (Tin et al., 2011). The potential for adapting such approaches to vegetative crops merits further study.

\section{CONCLUSIONS}

Seed systems in Vietnam and Cambodia's key cassava production areas were informal and self-regulated, with no active quality certification schemes. Traders played important roles in longdistance seed movement, yet in terms of predominant practice, transaction, and volumes, the use of farm-saved seed and exchanges among acquaintances within the community were most common. The notable exception was Tay Ninh, the highly commercialized "cassava seed basket" of Southern Vietnam, which has developed an integrated farmer-trader system characterized by frequent (often annual) sale and replacement of seed, and a high degree of financially motivated exchanges. However, full understanding of the trader network requires further study.

In both countries, $71-90 \%$ of seed used originated from within the commune, and $87-91 \%$ of provided planting materials also ended up replanted within the same commune. However, highintensity production areas such as Tay Ninh and Battambang supply long-distance, trader-mediated exchange.

International imports of seed into Cambodia from neighboring countries accounted for $20 \%$ of seed acquisitions, with the trade of hundreds of thousands of stakes to nine Cambodian provinces from Vietnam, to four provinces from Thailand, and to a single province from Laos. No outgoing exchanges from Cambodia were reported. Existing seed distribution networks originating in Thailand and Vietnam could be promising distribution hubs for the deployment of "clean seed" into the system, while Southern Vietnam and Northwestern Cambodia should be key areas for monitoring and surveillance for pest and disease.

Planned interventions in cassava seed systems should take into account the established relationships of informal actors including traders, root collection point owners, and starch factory owners and their relationships with farmers, and explore opportunities to empower their current roles in the seed network for phytosanitary monitoring, seed system upscaling, and farmer education campaigns. Combining seed network analysis with biophysical, epidemiological, and seed market evaluation can guide the design of effective interventions based on these existing networks.

Policies and regulations for more formal cassava seed systems do exist. However, innovations should be sought to increase the volume of available quality seed in light of emerging seed-borne pests and diseases. Models from other crops and contexts should be evaluated for adaptation, such as the use of QDS, positive and negative selection, and seed clubs.

\section{ETHICS STATEMENT}

The methods, data collection, and data handling protocols of this project were reviewed and approved by the International Center for Tropical Agriculture (CIAT) Institutional Review Board, and meet CIAT guidelines for research involving human subjects. Respondents provided oral informed consent prior to survey implementation, and all identifying data were anonymized in the resulting dataset. Participants in the bi-national survey, for whom plant tissue was also collected for SLCMV diagnostics, also provided written consent. This work received Institutional Review Board approval through the University of Florida IRB-02 number IRB201801981.

\section{DATA AVAILABILITY STATEMENT}

The anonymized farmer survey data collected in this project is available on CIAT's dataverse portal at the following DOI: https:// doi.org/10.7910/DVN/VVCX4J. 


\section{AUTHOR CONTRIBUTIONS}

$\mathrm{ED}, \mathrm{SdH}, \mathrm{DB}, \mathrm{NM}, \mathrm{KW}$, and JN conceived and designed the study. ED, SdH, KA, KG, MK, and JN designed household surveys, organized the database, performed descriptive statistics, and interpretation of results. $\mathrm{KA}, \mathrm{KG}$, and $\mathrm{ED}$ performed network analysis and interpretation of results. TC, MK, SS, PS, IP, NL, and NP supported with local expert input to study design, conducted survey implementation, and performed data collection and processing. $\mathrm{ED}, \mathrm{SdH}, \mathrm{CA}$, and PS wrote the manuscript. KA and KG reviewed the manuscript and provided additional inputs. All authors reviewed and approved the final manuscript.

\section{FUNDING}

This research was undertaken as part of the CGIAR Research Program on Roots, Tubers and Bananas (RTB). Funding support

\section{REFERENCES}

Almekinders, C. J. M., and Louwaars, N. P. (2002). The importance of the farmers' seed systems in a functional national seed sector. J. New Seeds 4, 15-33. doi: 10.1300/J153v04n01_02

Almekinders, C. J. M., Louwaars, N. P., and de Bruijn, G. (1994). Local seed systems and their importance for an improved seed supply in developing countries. Euphytica 78, 207-216. doi: 10.1007/BF00027519

Alvarez, E., Pardo, J. M., Mejía, J. F., Bertaccini, A., Thanh, N. D., and Hoat, T. X. (2013). Detection and identification of "Candidatus Phytoplasma asteris"related phytoplasmas associated with a witches' broom disease of cassava in Vietnam. Phytopathog. Moll. 3, 77-81. doi: 10.5958/j.2249-4677.3.2.018

Andersen, K. F., Buddenhagen, C. E., Rachkara, P., Gibson, R., Kalule, S., Phillips, D., et al. (2018). Modeling epidemics in seed systems to guide management strategies: the case of sweetpotato in Northern Uganda. BioRxiv [Preprint]. 1-35. doi: 10.1101/107359

ASF (2016). Access to Seed Index Report 2016. Access to Seed Foundation (ASF), Amsterdam, Holland.

Bentley, J., Olanrewaju, A., Madu, T., Olaosebikan, O., Abdoulaye, T., Wossen, T., et al. (2017). Cassava Farmers' Preferences for Varieties and Seed Dissemination System in Nigeria: Gender and Regional Perspectives. IITA Monograph, International Institute for Tropical Agriculture (IITA), Ibadan, Nigeria.

Bentley, J. W., Van Mele, P., and Reece, J. D. (2011). "How seed works," in African Seed Enterprises: Sowing the Seeds of Food Security, eds P. Van Mele, J. W. Bentley, and R. G. Guéi (CAB International, Wallingford, UK), 8-24. doi: $10.1079 / 9781845938437.0008$

Buddenhagen, C. E., Hernandez Nopsa, J. F., Andersen, K. F., AndradePiedra, J., Forbes, G. A., Kromann, P., et al. (2017). Epidemic network analysis for mitigation of invasive pathogens in seed systems: potato in Ecuador. Phytopathology 107, 1209-1218. doi: 10.1094/PHYTO-03-17-01 08-FI

Campo, B. V. H., Hyman, G., and Bellotti, A. (2011). Threats to cassava production: known and potential geographic distribution of four key biotic constraints. Food Security 3, 329-345. doi: 10.1007/s12571-011-0141-4

Castañeda-Méndez, O., Ogawa, S., Medina, A., Chavarriaga, P., and Gomez Selvara, M. (2017). A simple hydroponic hardening system and the effect of nitrogen source on the acclimation of in vitro cassava (Manihot esculenta Crantz). In Vitro Cell. Dev. Biol. Plant 53, 75-85. doi: 10.1007/s11627-016-9796-z

Ceballos, H., and Hershey, C. H. (2017). "Chapter 5: Cassava (Manihot esculenta Crantz)," in Genetic Improvement of Tropical Crops, eds H. Campos and P. D. S. Caligari (Springer; Springer International Publishing), 129-180. doi: 10.1007/978-3-319-59819-2 for this work was provided by Australian Center for International Agricultural Research (ACIAR, Project number: AGB/ 2016/032).

\section{ACKNOWLEDGMENTS}

The authors acknowledge the efforts of the survey implementation teams from the following institutions: Hung Loc Research Center, Vietnam; Tay Nguyen University, Vietnam; Battambang University, Cambodia; Royal University of Agriculture, Cambodia.

\section{SUPPLEMENTARY MATERIAL}

The Supplementary Material for this article can be found online at: https://www.frontiersin.org/articles/10.3389/fsufs. 2018.00073/full\#supplementary-material

Ceballos, H., Kawuki, R. S., Gracen, V. E., Yencho, G. C., and Hershey, C. H. (2015). Conventional breeding, marker-assisted selection, genomic selection and inbreeding in clonally propagated crops: a case study for cassava. Theor. Appl. Genet. 128, 1647-1667. doi: 10.1007/s00122-015-2555-4

Ceballos, H., Ramirez, J., Bellotti, A. C., Jarvis, A., and Alvarez, E. (2011). "Adaptation of cassava to changing climates," in Crop Adaptation to Climate Change, 1st Edn., eds S. S. Yadav, R. J. Redden, J. L. Hatfield, H. Lotze-Campen, and A. E. Hall (Hoboken, NJ: Blackwell Publishing; John Wiley \& Sons), 411-425. doi: 10.1002/9780470960929.ch28

Chadès, I., Martin, T. G., Nicol, S., Burgman, M. A., Possingham, H. P., and Buckley, Y. M. (2011). General rules for managing and surveying networks of pests, diseases, and endangered species. Proc. Natl. Acad. Sci. U.S.A. 108, 8323-8328. doi: 10.1073/pnas.1016846108

Christinck, A., Rattunde, F., Kergna, A., Mulinge, W., and Weltzien, E. (2018). Working Paper 165 Seed Systems - Insights from Kenya and Mali. Bonn.

Coomes, O. T. (2010). Of stakes, stems, and cuttings: the importance of local seed systems in traditional Amazonian societies. Profession. Geogr. 62, 323-334. doi: 10.1080/00330124.2010.483628

Coomes, O. T., McGuire, S. J., Garinec, E., Caillon, S., McKey, D., Demeulenaere, E., et al. (2015). Farmer seed networks make a limited contribution to agriculture? Four common misconceptions. Food Policy 56, 41-50. doi: 10.1016/j.foodpol.2015.07.008

Cramb, R., Manivong, V., Newby, J. C., Sothorn, K., and Sibat, P. S. (2017). Alternatives to land grabbing: exploring conditions for smallholder inclusion in agricultural commodity chains in Southeast Asia. J. Peasant Stud. 44, 813-841. doi: 10.1080/03066150.2016.12 42482

Csardi, G., and Nepusz, T. (2006). The igraph software package for complex network research. InterJ. Comp. Syst. 1695, 1-9. Available online at: http://www. interjournal.org/manuscript_abstract.php?361100992

Danso, K. E., and Ford-Lloyd, B. V. (2003). Encapsulation of nodal cuttings and shoot tips for storage and exchange of cassava germplasm. Plant Cell Rep. 21, 718-725. doi: 10.1007/s00299-003-0594-9

DARD (2018). Report on Cassava Production and Cassava CMD Prevention and Control in Tay Ninh and Next Steps. Department of Agriculture and Rural Development of Tay Ninh.

Delêtre, M., McKey, D. B., and Hodkinson, T. R. (2011). Marriage exchanges, seed exchanges, and the dynamics of manioc diversity. Proc. Natl. Acad. Sci. U.S.A. 108, 18249-18254. doi: 10.1073/pnas.1106259108

Duputié, A., David, P., Debain, C., and McKey, D. (2007). Natural hybridization between a clonally propagated crop, cassava (Manihot esculenta Crantz) and a wild relative in French Guiana. Mol. Ecol. 16, 3025-3038. doi: 10.1111/j.1365-294X.2007.03340.x 
Dyer, G., González, C., and Lopera, D. C. (2011). Informal "seed" systems and the management of gene flow in traditional agroecosystems: the case of cassava in Cauca, Colombia. PLoS ONE 6:e29067. doi: 10.1371/journal.pone.0029067

Elias, M., Lenoir, H., and McKey, D. (2007). Propagule quantity and quality in traditional Makushi farming of cassava (Manihot esculenta): a case study for understanding domestication and evolution of vegetatively propagated crops. Genet. Resour. Crop Evol. 54, 99-115. doi: 10.1007/s10722-005-2022-1

Elias, M., Rival, L., and Mckey, D. (2000). Perception and management of cassava (Manihot esculenta Crantz) diversity among Makushi Amerindians of Guyana (South America). J. Ethnobiol. 20, 239-265. Available online at: https:// ethnobiology.org/sites/default/files/pdfs/JoE/20-2/Elias-etal.pdf

Emperaire, L., Pinton, F., and Second, G. (1998). The dynamic management of varietal diversity in cassava in North-Western Amazonia. Nat. Sci. Soc. 6, 27-42. doi: 10.1016/S1240-1307(98)80006-X

FAO (2001). "A review of cassava in Asia with country case studies on Thailand and Vietnam," in Proceedings of the Validation Forum on the Global Cassava Development Strategy, Vol. 3 (Rome).

FAO (2010). Quality Declared Planting Material: Protocols and Standards for Vegetatively Propagated Crops. FAO Plant Protection and Production Paper 195. Food and Agriculture Organization of the United Nations (FAO), Rome.

Floro V. O. IV, Labarta, R. A., López-Lavalle, L. A. B., Martinez, J. M., and Ovalle, T. M. (2018). Household determinants of the adoption of improved cassava varieties using DNA fingerprinting to identify varieties in farmer fields: a case study in Colombia. J. Agric. Econ. 69, 518-536. doi: 10.1111/1477-9552. 12247

Fu, Y., Wangsomnuk, P. P., and Ruttawat, B. (2014). Thai elite cassava genetic diversity was fortuitously conserved through farming with different sets of varieties. Conserv. Genet. 15, 1463-1478. doi: 10.1007/s10592-014-0631-y

Garrett, K. A., Alcalá-Briseño, R. I., Andersen, K. F., Buddenhagen, C. E., Choudhury, R. A., Fulton, J. C., et al. (2018). Network analysis: a systems framework to address grand challenges in plant pathology. Annu. Rev. Phytopathol. 56, 559-580. doi: 10.1146/annurev-phyto-080516-035326

Garrett, K. A., Andersen, K. F., Asche, F., Bowden, R. L., Forbes, G. A., Kulakow, P. A., et al. (2017). Resistance genes in global crop breeding networks. Phytopathology 107, 1268-1278. doi: 10.1094/PHYTO-03-17-0082-FI

Graziosi, I., Minato, N., Alvarez, E., Ngo, D. T., Hoat, T. X., Aye, T. M., et al. (2016). Emerging pests and diseases of South-east Asian cassava: a comprehensive evaluation of geographic priorities, management options and research needs. Pest Manag. Sci. 72, 1071-1089. doi: 10.1002/ps.4250

GSO (2017). Planted Area of Cassava by Province. General Statistics Office, Government of Vietnam, Ministry of Planning and Investment. Available online at: http://gso.gov.vn/default_en.aspx?tabid=778 (Accessed August 2017).

Hegde, V., Makeshkumar, T., Sheela, M. N., Visalakshi Chandra, C., Koundinya, A. V. V., Anil, S. R., et al. (2016). Production of synthetic seed in cassava (Manihot esculenta Crantz). J. Root Crops 42, 5-9. Available online at: http://isrc.in/ojs/ index.php/jrc/article/view/407/290

Henry, G. (1991). Adoption of cassava technologies: constraints, strategies. Trends in CIAT Commodities 1991. Cali: CIAT. p. 22.

Hernandez Nopsa, J. F., Daglish, G. J., Hagstrum, D. W., Leslie, J. F., Phillips, T. W., Scoglio, C., et al. (2015). Ecological networks in stored grain: identifying key nodes for emerging pests and mycotoxins in postharvest networks. Bioscience 65, 985-1002. doi: 10.1093/biosci/biv122

Howeler, R. (2014). Sustainable Soil and Crop Management of Cassava in Asia: A Reference Manual. Cali: CIAT. Available online at: www.ciat.cgiar.org

Howeler, R. H., and Ceballos, H. (2006). "CIAT initiatives on cassava improvement in Asia," in Cassava's Potential in Asia in the 21st Century: Present Situation and Future Research and Development Needs: Proceedings of the sixth Regional Workshop, eds R. H. Howeler and S. L. Tan (Ho Chi Minh City: Centro Internacional de Agricultura Tropical), 25-31.

Kawa, N. C., McCarty, C., and Clement, C. R. (2013). Manioc varietal diversity, social networks, and distribution constraints in rural Amazonia. Curr. Anthropol. 54, 764-770. doi: 10.1086/673528

Legg, J. P. (1999). Emergence, spread and strategies for controlling the pandemic of cassava mosaic virus disease in east and central Africa. Crop Protect. 18, 627-637. doi: 10.1016/S0261-2194(99)00062-9

Legg, J. P., Jeremiah, S. C., Obiero, H. M., Maruthi, M. N., Ndyetabula, I., OkaoOkuja, G., et al. (2011). Comparing the regional epidemiology of the cassava mosaic and cassava brown streak virus pandemics in Africa. Virus Res. 159, 161-170. doi: 10.1016/j.virusres.2011.04.018

Legg, J. P., Lava Kumar, P., Makeshkumar, T., Tripathi, L., Ferguson, M., Kanju, E., et al. (2015). Cassava virus diseases: biology, epidemiology, and management. Adv. Virus Res. 91, 85-142. doi: 10.1016/bs.aivir.2014.10.001

Legg, J. P., Somado, E. A., Barker, I., Beach, L., Ceballos, H., Cuellar, W., et al. (2014). A global alliance declaring war on cassava viruses in Africa. Food Secur. 6, 231-248. doi: 10.1007/s12571-014-0 340-x

Longley, C., and Sperling, L. (2002). Beyond seeds and tools: effective support to farmers in emergencies. Disasters 26, 283-287. doi: 10.1111/1467-7717.00206

Lozano, J. C., Bellotti, A., Reyes, J. A., Howeler, R., Leihner, D., and Doll, J. (1981). Field Problems in Cassava. Cali. Colombia. Centro Internacional de Agricultura Tropical. p. 208.

Luby, C. H., and Goldman, I. L. (2016). Freeing crop genetics through the open source seed initiative. PLoS Biol. 14:e1002441. doi: 10.1371 /journal.pbio.1002441

Lyon, F. (2000). Trust, networks and norms: the creation of social capital in agricultural economies in Ghana. World Dev. 28, 663-681. doi: 10.1016/S0305-750X(99)00146-1

MAFF (2017). "Annual report for Agriculture Forestry and Fisheries 20162017 and direction 2018," in MAFF Conference (Phnom Penh: Ministry of Agriculture, Forestry and Fisheries, Kingdom of Cambodia).

Mallowa, S. O., Isutsa, D. K., Kamau, A. W., Obonyo, R., and Legg, J. P. (2006). Current characteristics of cassava mosaic disease in postepidemic areas increase the range of possible management options. Ann. Appl. Biol. 149, 137-144. doi: 10.1111/j.1744-7348.2006.00073.x

McGuire, S., and Sperling, L. (2013). Making seed systems more resilient to stress. Glob. Environ. Chang. 23, 644-653. doi: 10.1016/j.gloenvcha.2013. 02.001

McGuire, S., and Sperling, L. (2016). Seed systems smallholder farmers use. Food Secur. 8, 179-195. doi: 10.1007/s12571-015-0528-8

McGuire, S. J. (2008). Securing access to seed: social relations and sorghum seed exchange in Eastern Ethiopia. Hum. Ecol. 36, 217-229. doi: 10.1007/s10745-007-9143-4

McQuaid, C. F., Sseruwagi, P., Pariyo, A., and Van Den Bosch, F. (2016). Cassava brown streak disease and the sustainability of a clean seed system. Plant Pathol. 65, 299-309. doi: 10.1111/ppa.12453

Montenegro de Wit, M. (2017). Beating the bounds: how does "open source" become a seed commons? J. Peasant Stud. doi: 10.1080/03066150.2017.1383395. [Epub ahead of print].

Moslonka-Lefebvre, M., Finley, A., Dorigatti, I., Dehnen-Schmutz, K., Harwood, T., Jeger, M. J., et al. (2011). Networks in plant epidemiology: from genes to landscapes, countries, and continents. Phytopathology 101, 392-403. doi: 10.1094/PHYTO-07-10-0192

Nassar, N. M. A., and Ortiz, R. (2009). “Cassava genetic resources: manipulation for crop improvement," in Plant Breeding Reviews, Vol. 31, ed J. Janick (Hoboken, NJ: John Wiley \& Sons), 247-275. doi: 10.1002/97804705937 83.ch5

NIS (2017). Cambodia Socio-Economic Survey 2016. National Institute of Statistics (NIS), Ministry of Planning, Kingdom of Cambodia. Available online at: https:// www.nis.gov.kh/nis/CSES/Final\%20Report\%20CSES\%202016.pdf

Ospina, B., Jiménez, A., Lopez, V., Pantoja, A., Prakash, A., Gómez, et al. (2016). Cassava in the Carribean Region: A Look at the Potential of the Crop to Promote Agricultural Development and Economic Growth. Food and Agriculture Organization of the United Nations, Clayuca Corporation, and Inter American Institute for Cooperation on Agriculture. Bridgetown. Available online at: http://www.fao.org/documents/card/en/c/e5f1c41c-3a9e-4683-alf0a894f24e8f26

Patil, B. L., Legg, J. P., Kanju, E., and Fauquet, C. M. (2015). Cassava brown streak disease: a threat to food security in Africa. J. Gen. Virol. 96, 956-68. doi: 10.1099/vir.0.000014

Pautasso, M. (2015). Network simulations to study seed exchange for agrobiodiversity conservation. Agron. Sustain. Dev. 35, 145-150. doi: $10.1007 /$ s13593-014-0222-9

Pinton, F. (2003). Traditional knowledge and areas of biodiversity in Brazilian Amazonia. Int. J. Soc. Sci. 55, 607-618. doi: 10.1111/j.0020-8701.2003.0550 4010.x 
Rabbi, I. Y., Kulakow, P. A., Manu-Aduening, J. A., Dankyi, A. A., Asibuo, J. Y., Parkes, E. Y., et al. (2015). Tracking crop varieties using genotyping-by-sequencing markers: a case study using cassava (Manihot esculenta Crantz). BMC Genetics 16:115. doi: 10.1186/s12863-015-0273-1

Rachkara, P., Phillips, D. P., Kalule, S. W., and Gibson, R. W. (2017). Innovative and beneficial informal sweetpotato seed private enterprise in northern Uganda. Food Secur. 9, 595-610. doi: 10.1007/s12571-017-0680-4

Rajendran, P. G., Mohan, C., and Sreekumar, J. (2005). Standardization of true cassava seed (TCS) programme with special emphasis on more homogeneous, CMD resistant progenies. Euphytica 142, 13-22. doi: 10.1007/s10681-005-0318-z

Salick, J., Cellinese, N., and Knapp, S. (1997). Indigenous diversity of cassava: generation, maintenance, use and loss among the Amuesha, Peruvian upper Amazon. Econ. Bot. 51, 6-19. doi: 10.1007/BF02910400

Samberg, L. H., Shennan, C., and Zavaleta, E. (2013). Farmer seed exchange and crop diversity in a changing agricultural landscape in the southern highlands of Ethiopia. Hum. Ecol. 41, 477-485. doi: 10.1007/s10745-013-9579-7

Sardos, J., Mckey, D., Duval, M. F., Malapa, R., Noyer, J. L., and Lebot, V. (2008). Evolution of cassava (Manihot esculenta Crantz) after recent introduction into a South Pacific Island system: the contribution of sex to the diversification of a clonally propagated crop. Genome 51, 912-921. doi: 10.1139/G08-080

Shaw, M. W., and Pautasso, M. (2014). Networks and plant disease management: concepts and applications. Annu. Rev. Phytopathol. 52, 477-493. doi: 10.1146/annurev-phyto-102313-050229

Shiji, R., George, J., Sunitha, S., and Muthuraj, R. (2014). Micropropagation for rapid multiplication of planting material in cassava (Manihot esculenta Crantz). J. Root Crops 40, 1-8. Available online at: http://isrc.in/ojs/index.php/ jrc/article/view/229/84

Sinthuprama, S., and Tiraporn, C. (1986). "Improving the productivity of cassava in Thailand," in Cassava in Asia, Its Potential and Research Development Needs. Proceedings of a Regional Workshop (Bangkok), 277-287.

SNV (2015). Cassava Value Chain Analysis - Inclusive Business Model for Promoting Sustainable Smallholder Cassava Production (IBC). SNV, Phnom Penh, Cambodia.

Spielman, D. J., and Kennedy, A. (2016). Towards better metrics and policymaking for seed system development: Insights from Asia's seed industry. Agric. Syst. 147, 111-122. doi: 10.1016/j.agsy.2016.05.015

Sseruwagi, P., Sserubombwe, W. S., Legg, J. P., Ndunguru, J., and Thresh, J. M. (2004). Methods of surveying the incidence and severity of cassava mosaic disease and whitefly vector populations on cassava in Africa: a review. Virus Res. 100, 129-142. doi: 10.1016/j.virusres.2003.12.021

Sutrave, S., Scoglio, C., Isard, S. A., Hutchinson, J. M. S., and Garrett, K. A. (2012). Identifying highly connected counties compensates for resource limitations when evaluating national spread of an invasive pathogen. PLoS ONE 7:e37793. doi: 10.1371/journal.pone.0037793

Tadesse, Y., Almekinders, C. J. M., Schulte, R. P. O., and Struik, P. C. (2016). Tracing the seed: seed diffusion of improved potato varieties through farmers' networks in Chencha, Ethiopia. Expl. Agric. 147, 111-122. doi: $10.1017 /$ S001447971600051X

Thiele, G. (1999). Informal potato seed systems in the Andes: why are they important and what should we do with them? World Dev. 27, 83-99. doi: 10.1016/S0305-750X(98)00128-4

Thomas, M., and Caillon, S. (2016). Effects of farmer social status and plant biocultural value on seed circulation networks in Vanuatu. Ecol. Soc. 21:13. doi: 10.5751/ES-08378-210213

Thomas-Sharma, S., Andrade-Piedra, J., Carvajal Yepes, M., Hernandez Nopsa, J. F., Jeger, M. J., Jones, R. A. C., et al. (2017). A risk assessment framework for seed degeneration: informing an integrated seed health strategy for vegetatively propagated crops. Phytopathology 107, 1123-1135. doi: 10.1094/PHYTO-09-16-0340-R
Tin, H. Q., Cuc, N. H., Be, T. T., Ignacio, N., and Berg, T. (2011). Impacts of seed clubs in ensuring local seed systems in the Mekong Delta, Vietnam. J. Sustain. Agric. 35, 840-854. doi: 10.1080/10440046.2011.611746

Tripp, R. (1994). Biodiversity and modern crop varieties: sharpening the debate. Agric. Hum. Values 13, 48-63. doi: 10.1007/BF01530523

UPOV (1991). Act of 1991 International Convention for the Protection of New Varieties of Plants of 2 December 1961, as Revised at Geneva on 10 November 1972, 23 October 1978 and 19 March 1991. L192/64. Available online at: http://ec.europa.eu/world/agreements/prepareCreateTreatiesWorkspace/ treatiesGeneralData.do?step $=0$ \&redirect $=$ true\&treatyId $=6821$

Urrea-Hernandez, C., Almekinders, C. J. M., and van Dam, Y. K. (2016). Understanding perceptions of potato seed quality among small-scale farmers in Peruvian highlands. NJAS Wageningen J. Life Sci. 76, 21-28. doi: 10.1016/j.njas.2015.11.001

Van Dusen, M. E., and Taylor, J. E. (2005). Missing markets and crop diversity: evidence from Mexico. Environ. Dev. Econ. 10, 513-531. doi: 10.1017/S1355770X05002317

Violon, C., Thomas, M., and Garine, E. (2016). Good year, bad year: changing strategies, changing networks? A two-year study on seed acquisition in northern Cameroon. Ecol. Evol. 21:34. doi: 10.5751/ES-08376-2 10234

Wang, H. L., Cui, X. Y., Wang, X. W., Liu, S. S., Zhang, Z. H., and Zhou, X. P. (2016). First report of Sri Lankan cassava mosaic virus infecting Cassava in Cambodia. Plant Dis. 100, 1029-1029. doi: 10.1094/PDIS-10-15-122 8-PDN

Wattnem, T. (2016). Seed laws, certification and standardization: outlawing informal seed systems in the Global South. J. Peasant Stud. 43, 850-867. doi: 10.1080/03066150.2015.1130702

Wickham, H., and Francois, R. (2016). dplyr: A Grammar of Data Manipulation. $\mathrm{R}$ package version 0.5.0. Available online at: https://CRAN.R-project.org/ package $=$ dplyr

Wyckhuys, K. A., Graziosi, I., Burra, D. D., and Walter, A. J. (2017). Phytoplasma infection of a tropical root crop triggers bottom-up cascades by favoring generalist over specialist herbivores. PLOS ONE 12:e0182766. doi: 10.1371/journal.pone.0182766

Yonow, T., Kriticos, D. J., and Ota, N. (2017). The potential distribution of cassava mealybug (Phenacoccus manihoti), a threat to food security for the poor. PLoS ONE 12:e0173265. doi: 10.1371/journal.pone.0173265

Ziegler, A. D., Bruun, T. B., Guardiola-Claramonte, M., Giambelluca, T. W., Lawrence, D., and Lam, N. T. (2009). Environmental consequences of the demise in swidden cultivation in montane mainland Southeast Asia: hydrology and geomorphology. Hum. Ecol. 37, 361-373. doi: 10.1007/s10745-0099258-X

Zimmerer, K. S. (2003). Geographies of Seed Networks for Food Plants (Potato, Ulluco) and Approaches to Agrobiodiversity Conservation in the Andean Countries. Soc. Nat. Resour. 16, 583-601. doi: 10.1080/089419203 09185

Conflict of Interest Statement: The authors declare that the research was conducted in the absence of any commercial or financial relationships that could be construed as a potential conflict of interest.

Copyright (c) 2018 Delaquis, Andersen, Minato, Cu, Karssenberg, Sok, Wyckhuys, Newby, Burra, Srean, Phirun, Le, Pham, Garrett, Almekinders, Struik and de Haan. This is an open-access article distributed under the terms of the Creative Commons Attribution License (CC BY). The use, distribution or reproduction in other forums is permitted, provided the original author(s) and the copyright owner(s) are credited and that the original publication in this journal is cited, in accordance with accepted academic practice. No use, distribution or reproduction is permitted which does not comply with these terms. 